Cite this: RSC Adv., 2014, 4, 23068

\title{
A family of polynuclear cobalt complexes upon employment of an indeno-quinoxaline based oxime ligand $\dagger$
}

\author{
Angelos B. Canaj, ${ }^{a}$ Lydia E. Nodaraki, ${ }^{a}$ Katarzyna Ślepokura, ${ }^{\mathrm{b}}$ Milosz Siczek, ${ }^{\mathrm{b}}$ \\ Demetrios I. Tzimopoulos, ${ }^{c}$ Tadeusz Lis ${ }^{b}$ and Constantinos J. Milios ${ }^{\star a}$
}

The reaction of $\mathrm{Co}(\mathrm{OAc})_{2} \cdot 4 \mathrm{H}_{2} \mathrm{O}$ with $\mathrm{LH}(\mathrm{LH}=11 \mathrm{H}$-indeno[1,2-b]quinoxalin-11-one oxime) in $\mathrm{MeOH}$ in the presence of $\mathrm{NEt}_{3}$ forms the complex $\left[\mathrm{CO}_{2}{ }_{2} \mathrm{CO}{ }^{\prime \prime} \mathrm{O}(\mathrm{OAc})_{3} \mathrm{~L}_{3}\right] \cdot 0.5 \mathrm{MeOH} \cdot 0.2 \mathrm{H}_{2} \mathrm{O}\left(1 \cdot 0.5 \mathrm{MeOH} \cdot 0.2 \mathrm{H}_{2} \mathrm{O}\right)$, while repeating the reaction under solvothermal conditions yielded the heptanuclear cluster $\left[\mathrm{CO}_{7}{ }_{7} \mathrm{~L}_{9}\right.$ $\left.(\mathrm{OH})_{2}(\mathrm{OAc})_{2.7}(\mathrm{MeO})_{0.3}\left(\mathrm{H}_{2} \mathrm{O}\right)\right] \cdot 4.6 \mathrm{MeOH} \cdot 3.3 \mathrm{H}_{2} \mathrm{O}\left(2 \cdot 4.6 \mathrm{MeOH} \cdot 3.3 \mathrm{H}_{2} \mathrm{O}\right)$. Changing the starting metal salt to $\mathrm{Co}\left(\mathrm{ClO}_{4}\right)_{2} \cdot 6 \mathrm{H}_{2} \mathrm{O}$ and upon the reaction with $\mathrm{LH}$ in the presence of $\mathrm{NEt}_{3}$ under high temperature and pressure, we managed to isolate the decanuclear cluster $\left[\mathrm{CO}_{10}{ }_{10} \mathrm{~L}_{14}(\mathrm{OH})_{3.6}(\mathrm{MeO})_{0.4}\right]\left(\mathrm{ClO}_{4}\right)_{2} \cdot 8.5 \mathrm{MeOH} \cdot 5.75 \mathrm{H}_{2} \mathrm{O}$ $\left(3 \cdot 8.5 \mathrm{MeOH} \cdot 5.75 \mathrm{H}_{2} \mathrm{O}\right)$, while under normal bench conditions and upon employment of pivalates in the reaction mixture complex $\left[\mathrm{CO}_{4}{ }_{4} \mathrm{~L}_{4}(\text { piv })_{4}(\mathrm{MeOH})_{2}\right] \cdot \mathrm{MeOH} \cdot \mathrm{H}_{2} \mathrm{O}\left(4 \cdot \mathrm{MeOH} \cdot \mathrm{H}_{2} \mathrm{O}\right)$ was formed. Furthermore, the reaction of $\mathrm{Co}\left(\mathrm{ClO}_{4}\right)_{2} \cdot 6 \mathrm{H}_{2} \mathrm{O}$ with $\mathrm{LH}$ and aibH (2-amino-isobutyric acid) in the presence of $\mathrm{NEt}_{3}$ in $\mathrm{MeOH}$ gave the mononuclear complex $\left[\mathrm{Co}{ }^{\prime \prime \prime} \mathrm{L}(a i b)_{2}\right] \cdot 3 \mathrm{H}_{2} \mathrm{O}\left(5 \cdot 3 \mathrm{H}_{2} \mathrm{O}\right)$, while upon increasing the metal-ligand ratio cluster $\left[\mathrm{CO}_{2}{ }_{2} \mathrm{CO}_{4} \mathrm{~L}_{4}(\mathrm{aib})_{2}(\mathrm{OH})_{2}\right] \cdot 7.9 \mathrm{MeOH}(6 \cdot 7.9 \mathrm{MeOH})$ was isolated. Finally, repeating the reaction that yielded the mononuclear complex $5 \cdot 3 \mathrm{H}_{2} \mathrm{O}$ under solvothermal conditions, gave the octanuclear cluster $\left[\mathrm{CO}_{8}{ }_{8} \mathrm{~L}_{10}(\mathrm{aib})_{2}(\mathrm{MeO})_{2}\right]\left(\mathrm{ClO}_{4}\right)_{2} \cdot 6.8 \mathrm{MeOH} \cdot 7 \mathrm{H}_{2} \mathrm{O} \quad\left(7 \cdot 6.8 \mathrm{MeOH} \cdot 7 \mathrm{H}_{2} \mathrm{O}\right)$. Variable temperature dc magnetic susceptibility studies for complexes 2, 3, 4 and 7, reveal that all clusters display dominant antiferromagnetic interactions leading to small or diamagnetic ground-states, $\mathrm{S}$.

Received 5th March 2014 Accepted 12th May 2014 DOI: $10.1039 / c 4 r a 01914 h$ www.rsc.org/advances led to the synthesis of five nickel complexes with nuclearities ranging from 3 up to $8 .^{4}$ We have now expanded our studies

in $\mathrm{Co}(\mathrm{II} / \mathrm{III})$ chemistry, and herein we report the use of this

In the last few years metal-oxime coordination chemistry has proven to be a fruitful source for the synthesis and characterization of numerous metallic complexes. ${ }^{1}$ Although initially triggered by the employment of salicyl- and pyridyl-based oximes in manganese cluster chemistry, ${ }^{2}$ it later expanded to other $3 \mathrm{~d}, 4 \mathrm{f}$ and $3 \mathrm{~d}-4 \mathrm{f}$ clusters as well, while a palette of various oxime-based ligands is nowadays utilized for the synthesis of such species. ${ }^{3}$ In addition, many of these clusters have been found to display interesting magnetic properties, such as single molecule magnetism behaviour (SMM), i.e. they can retain their magnetization once magnetized at very low temperatures in the absence of an external magnetic field.

We recently reported the use of a new indeno-quinoxaline based oxime ligand, LH (Scheme 1), in Ni(II) chemistry, which

\footnotetext{
${ }^{a}$ Department of Chemistry, University of Crete, 71003 Herakleion, Greece. E-mail: komil@chemistry.uoc.gr; Tel: +30-2810-545099

${ }^{b}$ Faculty of Chemistry, University of Wroclaw, Joliot-Curie 14, 50-383 Wroclaw, Poland ${ }^{c}$ Department of Chemistry, Aristotle University of Thessaloniki, 54124, Thessaloniki, Greece

$\dagger$ Electronic supplementary information (ESI) available. CCDC 989901-989909. For ESI and crystallographic data in CIF or other electronic format see DOI: 10.1039/c4ra01914h
}

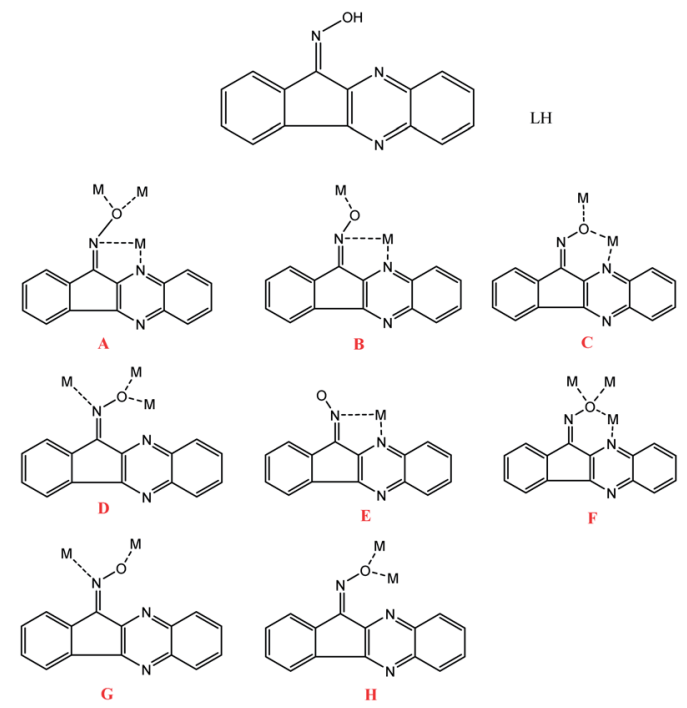

Scheme 1 The structure of LH (top) and its coordination modes in 1-7 (bottom) 
indeno-quinoxaline oxime ligand for the synthesis of an extended family of cobalt complexes.

\section{Experimental}

\section{Materials and physical measurements}

All manipulations were performed under aerobic conditions using materials as received (reagent grade). Caution! Although we encountered no problems, care should be taken when using the potentially explosive perchlorate ions. LH was synthesized as described in the literature. ${ }^{5}$ Elemental analyses $(\mathrm{C}, \mathrm{H}, \mathrm{N})$ were performed by the University of Ioannina microanalysis service. Variable-temperature, solid-state direct current (dc) magnetic susceptibility data down to $5.0 \mathrm{~K}$ were collected on a Quantum Design MPMS-XL SQUID magnetometer (University of Crete) equipped with a $7 \mathrm{~T}$ dc magnet. Diamagnetic corrections were applied to the observed paramagnetic susceptibilities using Pascal's constants.

\section{Syntheses}

$\left[\mathrm{Co}_{3} \mathrm{O}(\mathrm{OAc})_{3} \mathrm{~L}_{3}\right] \cdot 0.5 \mathrm{MeOH} \cdot 0.2 \mathrm{H}_{2} \mathrm{O}\left(1 \cdot 0.5 \mathrm{MeOH} \cdot 0.2 \mathrm{H}_{2} \mathrm{O}\right)$. $\mathrm{Co}(\mathrm{OAc})_{2} \cdot 4 \mathrm{H}_{2} \mathrm{O}(124 \mathrm{mg}, 0.5 \mathrm{mmol}), \mathrm{LH}(124 \mathrm{mg}, 0.5 \mathrm{mmol})$ and $\mathrm{NEt}_{3}(2.0 \mathrm{mmol})$ were added in $\mathrm{MeOH}(20 \mathrm{ml})$ and the resulting mixture was stirred for $45^{\prime}$. The solution was filtrated and allowed to evaporate in room temperature. After 2 days, pink crystals of $\left[\mathrm{Co}_{3} \mathrm{O}(\mathrm{OAc})_{3} \mathrm{~L}_{3}\right] \cdot 0.5 \mathrm{MeOH} \cdot 0.2 \mathrm{H}_{2} \mathrm{O}$ were obtained in $\sim 40 \%$ yield and collected by filtration, washed with $\mathrm{Et}_{2} \mathrm{O}$ and dried in air. The complex analysed as solvent-free. Anal. calcd for $\mathrm{C}_{51} \mathrm{H}_{33} \mathrm{~N}_{9} \mathrm{Co}_{3} \mathrm{O}_{10}$ : C, 55.25; H, 3.00; N, 11.37. Found: C, 55.39; $\mathrm{H}, 3.27$; N, $11.23 \%$.

$\left[\mathrm{Co}_{7} \mathrm{~L}_{9}(\mathrm{OH})_{2}(\mathrm{OAc})_{2.7}(\mathrm{MeO})_{0.3}\left(\mathrm{H}_{2} \mathrm{O}\right)\right] \cdot 4.6 \mathrm{MeOH} \cdot 3.3 \mathrm{H}_{2} \mathrm{O}(2 \cdot 4.6-$ $\left.\mathrm{MeOH} \cdot 3.3 \mathrm{H}_{2} \mathrm{O}\right) \cdot \mathrm{Co}(\mathrm{OAc})_{2} \cdot 4 \mathrm{H}_{2} \mathrm{O}(124 \mathrm{mg}, 0.5 \mathrm{mmol}), \mathrm{LH}(124$ $\mathrm{mg}, 0.5 \mathrm{mmol})$ and $\mathrm{NEt}_{3}(2.0 \mathrm{mmol})$ were added in $\mathrm{MeOH}(10 \mathrm{ml})$ and the resulting mixture was transferred to a Teflon-lined autoclave and kept at $120{ }^{\circ} \mathrm{C}$ for 12 hours. After slow cooling to room temperature, pink crystals of $\left[\mathrm{Co}_{7} \mathrm{~L}_{9}(\mathrm{OH})_{2}(\mathrm{OAc})_{2.7}(\mathrm{MeO})_{0.3}\left(\mathrm{H}_{2} \mathrm{O}\right)\right]$. $4.6 \mathrm{MeOH} \cdot 3.3 \mathrm{H}_{2} \mathrm{O}$ were obtained in $\sim 35 \%$ yield and collected by filtration, washed with $\mathrm{Et}_{2} \mathrm{O}$ and dried in air. The complex analysed as $2 \cdot \mathrm{MeOH} \cdot \mathrm{H}_{2} \mathrm{O}$. Anal. calcd for $\mathrm{C}_{141.7} \mathrm{H}_{91} \mathrm{~N}_{27} \mathrm{Co}_{7} \mathrm{O}_{19.7}: \mathrm{C}$, 58.70; H, 3.16; N, 13.04. Found: C, 58.79; H, 3.41; N, 12.86\%.

$\left[\mathrm{Co}_{10} \mathrm{~L}_{14}(\mathrm{OH})_{3.6}(\mathrm{MeO})_{0.4}\right]\left(\mathrm{ClO}_{4}\right)_{2} \cdot 8.5 \mathrm{MeOH} \cdot 5.75 \mathrm{H}_{2} \mathrm{O}(3 \cdot 8.5-$ $\left.\mathrm{MeOH} \cdot 5.75 \mathrm{H}_{2} \mathrm{O}\right) . \quad \mathrm{Co}\left(\mathrm{ClO}_{4}\right)_{2} \cdot 6 \mathrm{H}_{2} \mathrm{O}(183 \mathrm{mg}, 0.5 \mathrm{mmol}), \mathrm{LH}$ $(124 \mathrm{mg}, 0.5 \mathrm{mmol})$ and $\mathrm{NEt}_{3}(2.0 \mathrm{mmol})$ were added in $\mathrm{MeOH}$ $(10 \mathrm{ml})$ and the resulting mixture was transferred to a Teflonlined autoclave and kept at $120{ }^{\circ} \mathrm{C}$ for 12 hours. After slow cooling to room temperature, pink-red crystals of $\left[\mathrm{Co}_{10} \mathrm{~L}_{14}(\mathrm{OH})_{3.6}(\mathrm{MeO})_{0.4}\right]\left(\mathrm{ClO}_{4}\right)_{2} \cdot 8.5 \mathrm{MeOH} \cdot 5.75 \mathrm{H}_{2} \mathrm{O}$ were obtained in $\sim 25 \%$ yield and collected by filtration, washed with $\mathrm{Et}_{2} \mathrm{O}$ and dried in air. The complex analysed as $3 \cdot \mathrm{MeOH} \cdot 2 \mathrm{H}_{2} \mathrm{O}$. Anal. calcd for $\mathrm{C}_{211.4} \mathrm{H}_{124.8} \mathrm{~N}_{42} \mathrm{Co}_{10} \mathrm{O}_{29} \mathrm{Cl}_{2}$ : C, 58.00; H, 2.87; N, 13.44 . Found: C, 58.20; H, 3.13; N, 13.27\%.

$\left[\mathrm{Co}_{4} \mathrm{~L}_{4}(\text { piv })_{4}(\mathbf{M e O H})_{2}\right] \cdot \mathbf{M e O H} \cdot \mathbf{H}_{2} \mathbf{O}\left(\mathbf{4} \cdot \mathbf{M e O H} \cdot \mathbf{H}_{2} \mathbf{O}\right)$. The same procedure as that followed for complex $3 \cdot 8.5 \mathrm{MeOH} \cdot 5.75 \mathrm{H}_{2} \mathrm{O}$ was employed, with the addition of Napiv (0.062 mg, $0.5 \mathrm{mmol}$ ) in the reaction mixture. Pink crystals of $\left[\mathrm{Co}_{4} \mathrm{~L}_{4}(\mathrm{piv})_{4}(\mathrm{MeOH})_{2}\right]$. $\mathrm{MeOH} \cdot \mathrm{H}_{2} \mathrm{O}$ were formed after 3 days in $\sim 35 \%$ yield. The complex analysed as solvent-free. Anal. calcd for $\mathrm{C}_{82} \mathrm{H}_{76} \mathrm{~N}_{12} \mathrm{Co}_{4} \mathrm{O}_{14}: \mathrm{C}, 58.30 ; \mathrm{H}, 4.53 ; \mathrm{N}, 9.95$. Found: $\mathrm{C}, 58.17 ; \mathrm{H}$, 4.79 ; N, 10.05\%.

$\left[\mathrm{CoL}(\text { aib })_{2}\right] \cdot 3 \mathrm{H}_{2} \mathrm{O}\left(\mathbf{5} \cdot 3 \mathrm{H}_{2} \mathrm{O}\right) \cdot \mathrm{Co}\left(\mathrm{ClO}_{4}\right)_{2} \cdot 6 \mathrm{H}_{2} \mathrm{O}(183 \mathrm{mg}, 0.5$ $\mathrm{mmol}), \mathrm{LH}$ (124 mg, $0.5 \mathrm{mmol}$ ), aibH (52 $\mathrm{mg}, 0.5 \mathrm{mmol}$ ) and $\mathrm{NEt}_{3}(2.0 \mathrm{mmol})$ were added in $\mathrm{MeOH}(20 \mathrm{ml})$ and the resulting mixture was kept under stirring for $45^{\prime}$. The solution was then filtrated and allowed to evaporate in room temperature. After 1 day, dark pink crystals of $\left[\mathrm{CoL}(\mathrm{aib})_{2}\right] \cdot 3 \mathrm{H}_{2} \mathrm{O}$ were obtained in $\sim 50 \%$ yield and collected by filtration, washed with $\mathrm{Et}_{2} \mathrm{O}$ and dried in air. The complex analysed as $\mathbf{5} \cdot \mathrm{H}_{2} \mathrm{O}$. Anal. calcd for $\mathrm{C}_{23} \mathrm{H}_{26} \mathrm{~N}_{5} \mathrm{CoO}_{6}$ : C, 52.38; H, 4.97; N, 13.28. Found: C, 52.27; H, $5.22 ; \mathrm{N}, 13.47 \%$.

$\left[\mathrm{Co}_{3} \mathrm{~L}_{4}(\mathrm{aib})_{2}(\mathrm{OH})_{2}\right] \cdot 7.9 \mathrm{MeOH} \quad(6 \cdot 7.9 \mathrm{MeOH}) . \quad$ The same procedure as that followed for complex $5 \cdot 3 \mathrm{H}_{2} \mathrm{O}$ was employed, with the addition of excess of $\mathrm{Co}\left(\mathrm{ClO}_{4}\right)_{2} \cdot 6 \mathrm{H}_{2} \mathrm{O}(732 \mathrm{mg}, 2.0$ $\mathrm{mmol})$ in the reaction mixture. After 3 days, pink crystals of $\left[\mathrm{Co}_{3} \mathrm{~L}_{4}(\mathrm{aib})_{2}(\mathrm{OH})_{2}\right] \cdot 7.9 \mathrm{MeOH}$ were obtained in $\sim 40 \%$ yield and collected by filtration, washed with $\mathrm{Et}_{2} \mathrm{O}$ and dried in air. The complex analysed as $7 \cdot 2 \mathrm{MeOH}$. Anal. calcd for $\mathrm{C}_{70} \mathrm{H}_{58} \mathrm{~N}_{14} \mathrm{Co}_{3} \mathrm{O}_{12}$ : C, 57.42; H, 3.99; N, 13.39. Found: C, 57.55; $\mathrm{H}, 4.27$; N, $13.25 \%$.

$\left[\mathrm{Co}_{8} \mathrm{~L}_{10}(\mathrm{aib})_{2}(\mathrm{MeO})_{2}\right]\left(\mathrm{ClO}_{4}\right)_{2} \cdot 6.8 \mathrm{MeOH} \cdot 7 \mathrm{H}_{2} \mathrm{O}\left(7 \cdot 6.8 \mathrm{MeOH} \cdot 7 \mathrm{H}_{2} \mathrm{O}\right)$ and $\left[\mathrm{Co}_{8} \mathrm{~L}_{10}(\mathrm{aib})_{2}(\mathrm{MeO})_{2}\right]\left(\mathrm{ClO}_{4}\right)_{2} \cdot \mathrm{MeOH} \cdot 3 \mathrm{H}_{2} \mathrm{O} \quad\left(7 \cdot \mathrm{MeOH} \cdot 3 \mathrm{H}_{2} \mathrm{O}\right)$. $\mathrm{Co}\left(\mathrm{ClO}_{4}\right)_{2} \cdot 6 \mathrm{H}_{2} \mathrm{O}$ (183 mg, $\left.0.5 \mathrm{mmol}\right), \mathrm{LH}(124 \mathrm{mg}, 0.5 \mathrm{mmol})$, aibH $(52 \mathrm{mg}, 0.5 \mathrm{mmol})$ and $\mathrm{NEt}_{3}(2.0 \mathrm{mmol})$ were added in $\mathrm{MeOH}(10 \mathrm{ml})$ and the resulting mixture was transferred to a Teflon-lined autoclave and kept at $120{ }^{\circ} \mathrm{C}$ for 12 hours. After slow cooling to room temperature, two kinds of crystals, dark brown $7 \cdot 6.8 \mathrm{MeOH} \cdot 7 \mathrm{H}_{2} \mathrm{O}$ and pale brown $7 \cdot \mathrm{MeOH} \cdot 3 \mathrm{H}_{2} \mathrm{O}$, were obtained in $\sim 35 \%$ yield and collected by filtration, washed with $\mathrm{Et}_{2} \mathrm{O}$ and dried in air. The complex analysed as $7 \cdot \mathrm{MeOH} \cdot 3 \mathrm{H}_{2} \mathrm{O}$. Anal. calcd for $\mathrm{C}_{160} \mathrm{H}_{108} \mathrm{~N}_{32} \mathrm{Co}_{8} \mathrm{O}_{27} \mathrm{Cl}_{2}$ : C, 55.65; H, 3.15; N, 12.98. Found: C, 55.79; $\mathrm{H}, 3.36$; N, 12.85\%.

\section{X-ray crystallography}

Diffraction data for complexes 1, 3, 4 and 6 at low temperatures were collected on an Xcalibur R diffractometer with CCD Ruby and for 2, 5 and 7 on a KM4 diffractometer with a CCD Sapphire camera and Mo $\mathrm{K} \alpha$ radiation $(\lambda=0.71073 \AA)$. The crystal for 3 was slowly cooled from $230 \mathrm{~K}$ to $80 \mathrm{~K}$, at which data collection was carried out. All structures were solved by direct methods and refined by full-matrix least-squares techniques on $\mathrm{F}^{2}$ (SHELXL-97). ${ }^{6}$ Data collection parameters and structure solution and refinement details are listed in Table $\mathrm{S} 1 . \dagger$

\section{Results and discussion}

\section{Syntheses}

The reaction between $\mathrm{Co}(\mathrm{OAc})_{2} \cdot 4 \mathrm{H}_{2} \mathrm{O}$ and $\mathrm{LH}$ in the presence of base $\left(\mathrm{NEt}_{3}\right)$ in $\mathrm{MeOH}$ yields the trinuclear cluster $\left[\mathrm{Co}^{\mathrm{III}}{ }_{2} \mathrm{Co}^{\mathrm{II}} \mathrm{O}(\mathrm{OAc})_{3} \mathrm{~L}_{3}\right] \cdot 0.5 \mathrm{MeOH} \cdot 0.2 \mathrm{H}_{2} \mathrm{O} \quad\left(\mathbf{1} \cdot 0.5 \mathrm{MeOH} \cdot 0.2 \mathrm{H}_{2} \mathrm{O}\right)$ in moderate yield. Given the employment of excess base in the reaction, it is reasonable that all of the $\mathrm{LH}$ ligands found in $\mathbf{1}$ were in their deprotonated monoanionic form, $\mathrm{L}^{-}$. Furthermore, the acetates present in the reaction can also act as a base, 
thus aiding the deprotonation of the ligand. Two of the three metallic centers were oxidized in the +3 oxidation state, presumably upon oxidation from the atmospheric dioxygen, a commonly observed phenomenon in cobalt chemistry. In order to investigate the effect of high pressure/temperature on the identity of the product, we repeated the same reaction under solvothermal conditions, and we obtained the heptanuclear cluster $\left[\mathrm{Co}^{\mathrm{II}}{ }_{7} \mathrm{~L}_{9}(\mathrm{OH})_{2}(\mathrm{OAc})_{2.7}(\mathrm{MeO})_{0.3}\left(\mathrm{H}_{2} \mathrm{O}\right)\right] \cdot 4.6 \mathrm{MeOH} \cdot 3.6 \mathrm{H}_{2} \mathrm{O}$ $\left(2 \cdot 4.6 \mathrm{MeOH} \cdot 3.6 \mathrm{H}_{2} \mathrm{O}\right)$ according to eqn (1), proving the effect of the solvothermal conditions on increasing the nuclearity of the product:

$$
\begin{aligned}
& 7 \mathrm{Co}(\mathrm{OAc})_{2} \cdot 4 \mathrm{H}_{2} \mathrm{O}+9 \mathrm{LH} \\
& \stackrel{\mathrm{MeOH}}{\longrightarrow}\left[\mathrm{Co}^{\mathrm{II}} \mathrm{L}_{9}(\mathrm{OH})_{2}(\mathrm{OAc})_{2.7}(\mathrm{MeO})_{0.3}\left(\mathrm{H}_{2} \mathrm{O}\right)\right] \\
&+11.3 \mathrm{AcOH}+25 \mathrm{H}_{2} \mathrm{O}
\end{aligned}
$$

Furthermore, the oxidation of the metallic centers is now suppressed, since in the trinuclear cluster the ratio of $\mathrm{Co}^{\mathrm{III}}: \mathrm{Co}^{\mathrm{II}}$ was $2: 1$, while in the heptanuclear cluster all cobalt centers are maintained in the $2+$ oxidation state, due to the "reducing" environment present within the autoclaves under high temperature/pressure. ${ }^{7}$ Upon removal of the carboxylates from the reaction mixture, and changing $\mathrm{Co}(\mathrm{OAc})_{2} \cdot 4 \mathrm{H}_{2} \mathrm{O}$ to $\mathrm{Co}\left(\mathrm{ClO}_{4}\right)_{2} \cdot 6 \mathrm{H}_{2} \mathrm{O}$ we managed to isolate the decanuclear cluster $\left[\mathrm{Co}^{\mathrm{II}}{ }_{10} \mathrm{~L}_{14}(\mathrm{OH})_{3.6}(\mathrm{MeO})_{0.4}\right]$ $\left(\mathrm{ClO}_{4}\right)_{2} \cdot 8.5 \mathrm{MeOH} 5.75 \mathrm{H}_{2} \mathrm{O}\left(3 \cdot 8.5 \mathrm{MeOH} \cdot 5.75 \mathrm{H}_{2} \mathrm{O}\right)$ according to eqn (2):

$$
\begin{aligned}
& 10 \mathrm{Co}\left(\mathrm{ClO}_{4}\right)_{2} \cdot 6 \mathrm{H}_{2} \mathrm{O}+14 \mathrm{LH} \\
& \stackrel{\mathrm{MeOH}}{\longrightarrow}\left[\mathrm{Co}^{\mathrm{II}}{ }_{10} \mathrm{~L}_{14}(\underset{3}{\mathrm{OH}})_{4}\right]\left(\mathrm{ClO}_{4}\right)_{2}+18 \mathrm{ClO}_{4}^{-}+18 \mathrm{H}^{+}+56 \mathrm{H}_{2} \mathrm{O}
\end{aligned}
$$

While the reaction forming 3 under normal laboratory conditions did not lead to the formation of any crystalline product, upon addition of pivalates in the reaction mixture we were able to isolate the tetranuclear cluster $\left[\mathrm{Co}^{\mathrm{II}}{ }_{4} \mathrm{~L}_{4}(\mathrm{piv})_{4}(\mathrm{MeOH})_{2}\right] \cdot \mathrm{MeOH} \cdot \mathrm{H}_{2} \mathrm{O}\left(4 \cdot \mathrm{MeOH} \cdot \mathrm{H}_{2} \mathrm{O}\right)$, according to eqn (3):

$$
\begin{aligned}
& 4 \mathrm{Co}\left(\mathrm{ClO}_{4}\right)_{2} \cdot 6 \mathrm{H}_{2} \mathrm{O}+4 \mathrm{LH}+4 \mathrm{Napiv}+2 \mathrm{MeOH} \\
& \qquad \stackrel{\mathrm{MeOH}}{\longrightarrow}\left[\mathrm{Co}^{\mathrm{II}}{ }_{4} \mathrm{~L}_{4}(\mathrm{piv})_{4}(\mathrm{MeOH})_{2}\right]+4 \mathrm{NaClO}_{4}+4 \mathrm{H}^{+} \\
& \quad+4 \mathrm{ClO}_{4}^{-}+24 \mathrm{H}_{2} \mathrm{O}
\end{aligned}
$$

With the identity of cluster 4 established, we checked whether addition of other carboxylates would lead to analogous tetranuclear clusters. Therefore, we employed the artificial amino acid 2-amino-isobutyric acid, aibH, and we managed to characterize the mononuclear complex $\left[\mathrm{Co}^{\mathrm{III}} \mathrm{L}(\mathrm{aib})_{2}\right] \cdot 3 \mathrm{H}_{2} \mathrm{O}$ $\left(5 \cdot 3 \mathrm{H}_{2} \mathrm{O}\right)$, whose identity was not surprising given the chelate coordination mode of the amino acid ligand (vide infra). In order to increase the nuclearity of the cluster, we increased the metal-ligands ratio as a means of "forcing" the cluster to propagate into bigger species due to the lack of sufficient number of chelates. Indeed, upon repeating the same reaction with twice the initial metal salt concentration, we isolated the trinuclear complex $\quad\left[\mathrm{Co}_{2}{ }_{2} \mathrm{Co}^{\mathrm{II}} \mathrm{L}_{4}(\mathrm{aib})_{2}(\mathrm{OH})_{2}\right] \cdot 7.9 \mathrm{MeOH}$ $(6 \cdot 7.9 \mathrm{MeOH})$ in moderate yields. Furthermore, repeating the reaction that yielded the mononuclear complex $5 \cdot 3 \mathrm{H}_{2} \mathrm{O}$ under solvothermal conditions, gave the octanuclear cluster $\left[\mathrm{Co}^{\mathrm{II}}{ }_{8-}\right.$ $\left.\mathrm{L}_{10}(\mathrm{aib})_{2}(\mathrm{MeO})_{2}\right]\left(\mathrm{ClO}_{4}\right)_{2} \cdot 6.8 \mathrm{MeOH} \cdot 7 \mathrm{H}_{2} \mathrm{O} \quad\left(7 \cdot 6.8 \mathrm{MeOH} \cdot 7 \mathrm{H}_{2} \mathrm{O}\right)$ according to eqn (4):

$$
\begin{aligned}
8 \mathrm{Co}\left(\mathrm{ClO}_{4}\right)_{2} \cdot 6 & \mathrm{H}_{2} \mathrm{O}+10 \mathrm{LH}+2 \mathrm{aibH} \\
& +2 \mathrm{MeOH} \stackrel{\mathrm{MeOH}}{\longrightarrow}\left[\mathrm{Co}_{8} \mathrm{~L}_{10}(\mathrm{aib})_{2}(\mathrm{MeO})_{2}\right]\left(\mathrm{ClO}_{4}\right)_{2} \\
& +14 \mathrm{ClO}_{4}^{-}+14 \mathrm{H}^{+}+48 \mathrm{H}_{2} \mathrm{O}
\end{aligned}
$$

Finally, even though the formation of the complexes containing trivalent $\mathrm{Co}^{\mathrm{III}}$ ions, clusters $\mathbf{1}, 5$ and 6, cannot be "strictly" given by chemical equations since we are not absolutely sure of the oxidizing-reduced species, their formation can be possibly described by the following eqn (5)-(7), assuming that he most likely oxidizing agent responsible for the Co(II) to $\mathrm{Co}$ (III) transformation is $\mathrm{O}_{2}$ :

$$
\begin{aligned}
& 3 \mathrm{Co}(\mathrm{OAc})_{2} \cdot 4 \mathrm{H}_{2} \mathrm{O}+3 \mathrm{HL}+1 / 2 \mathrm{O}_{2} \\
& \stackrel{\mathrm{MeOH}}{\longrightarrow}\left[\mathrm{Co}_{2}^{\mathrm{III}}{ }_{2} \mathrm{Co}_{1}^{\mathrm{II}} \mathrm{O}(\mathrm{OAc})_{3} \mathrm{~L}_{3}\right]+3 \mathrm{AcOH}+12 \mathrm{H}_{2} \mathrm{O}
\end{aligned}
$$

$$
\begin{aligned}
2 \mathrm{Co}\left(\mathrm{ClO}_{4}\right)_{2} \cdot 6 \mathrm{H}_{2} \mathrm{O}+4 \mathrm{aibH}+2 \mathrm{HL}+1 / 2 \mathrm{O}_{2} \\
\stackrel{\mathrm{MeOH}}{\longrightarrow} 2\left[\mathrm{Co}_{5}^{\mathrm{III}} \mathrm{L}(\mathrm{aib})_{2}\right]+13 \mathrm{H}_{2} \mathrm{O}+4 \mathrm{HClO}_{4}
\end{aligned}
$$

$$
\begin{aligned}
3 \mathrm{Co}\left(\mathrm{ClO}_{4}\right)_{2} \cdot 6 \mathrm{H}_{2} \mathrm{O}+4 \mathrm{HL}+ & 2 \mathrm{aibH}+1 / 2 \mathrm{O}_{2} \\
& \stackrel{\mathrm{MeOH}}{\longrightarrow}\left[\mathrm{Co}^{\mathrm{III}}{ }_{2} \mathrm{Co}^{\mathrm{II}} \mathrm{L}_{4}(\mathrm{aib})_{2}(\mathrm{OH})_{2}\right] \\
& +6 \mathrm{HClO}_{4}+17 \mathrm{H}_{2} \mathrm{O}{ }^{6}
\end{aligned}
$$

\section{Description of structures}

The molecular structures of complexes 1-7 are presented in Fig. 1-7, while selected interatomic distances and angles are listed in Tables S2-8. $\dagger$ Cluster 1 crystallizes in the trigonal $R \overline{3}$ space group. Its structure (Fig. 1) describes an oxo-centered equilateral triangular unit, which consists of three diatomic (-N-O-) oximate bridges, from three deprotonated $\mathrm{L}^{-}$ligands, and three $\eta^{1}: \eta^{1}: \mu$ acetate ligands. All $\mathrm{L}^{-}$ligands adopt coordination mode $\mathrm{B}$ (Scheme 1), while each Co center is in a cis $-\mathrm{O}_{4} \mathrm{~N}_{2}$ coordination sphere. The formula of the molecule necessitates a $\left[\mathrm{Co}^{\mathrm{III}}{ }_{2} \mathrm{Co}^{\mathrm{II}}\right]$ oxidation states' distribution, but since the molecule lies on a special position (on a three-fold axis), and is disordered around it, we cannot assign the oxidation states of the metallic atoms. Similar examples of disordered mixed oxidation states have been previously reported in the literature. ${ }^{8}$

Complex 2 crystallizes in the triclinic $P \overline{1}$ space group. Its core (Fig. 2) describes an almost planar heptametallic disc. The metallic disk is held together via nine deprotonated monoanionic $\mathrm{L}^{-}$ligands, three acetate and two methoxide ligands. The nine $\mathrm{L}^{-}$ligands found in the structure, adopt four different coordination modes: (i) four are found in mode B (Scheme 1), forming a chelate ring via the oximate and one aromatic $\mathrm{N}$ atoms and bridging to a further Co center via the $\mathrm{O}_{\text {oximate }}$ atom, (ii) two form a chelate ring via the oximate and one aromatic $\mathrm{N}$ atoms and bridging to two further Co centers via the $\mu-\mathrm{O}_{\text {oximate }}$ atom (mode A), (iii) two are found in a rather unusual mode, 


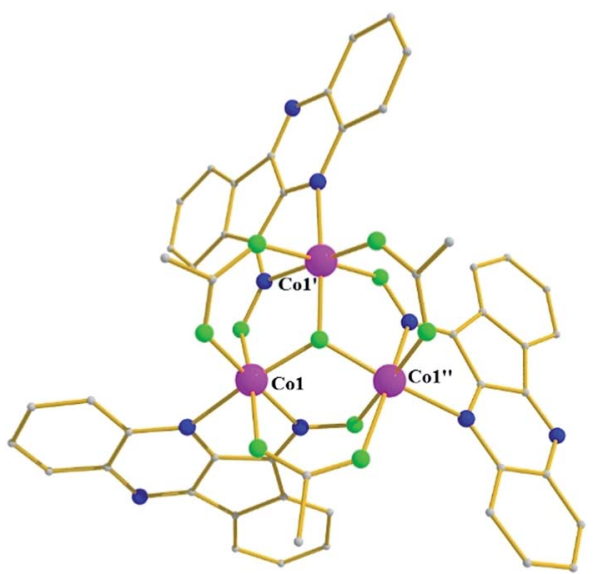

Fig. 1 Molecular structure of complex 1. Color code: $\mathrm{Co}=$ pink, $\mathrm{O}=$ green, $\mathrm{N}=$ blue, $\mathrm{C}=$ grey. Minor components of acetate and $\mathrm{H}$ atoms are omitted for clarity.

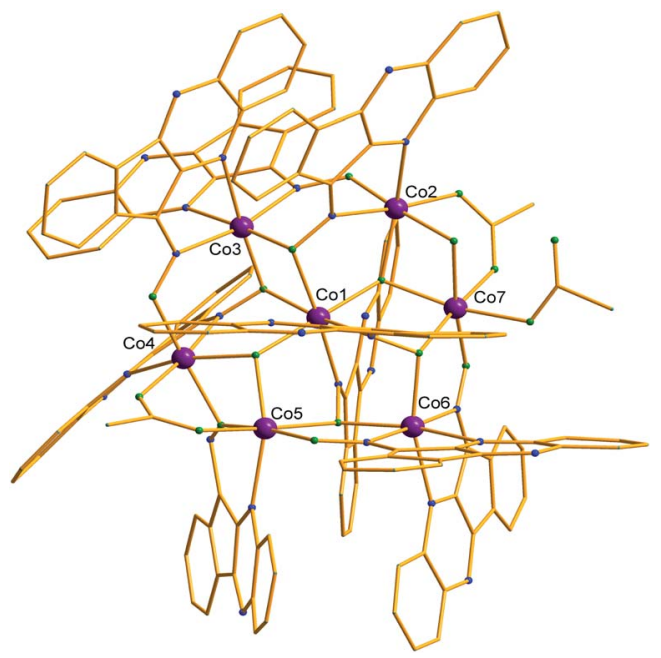

Fig. 2 Molecular structure of cluster 2. Color code: same as in Fig. 1. Disorder and $\mathrm{H}$ atoms as well as solvent molecules not shown for clarity.

bridging three metals via the monoatomic $\mu$ - $\mathrm{O}_{\text {oximate }}$ bridge and the $\mathrm{N}_{\text {oximate }}$ atom (mode $\mathrm{D}$ ), and (iv) one in mode $\mathrm{C}$ (Scheme 1) via the $\mathrm{O}_{\text {oximate }}$ and $\mathrm{N}_{\text {aromatic }}$ atoms. Two acetate ligands adopt the usual $\eta^{1}: \eta^{1}: \mu$ mode, while the third one is found terminally bound. Finally, the two hydroxides are found in a $\mu_{3}$ fashion, and in addition a $\mathrm{H}_{2} \mathrm{O}$ molecule bridges $\mathrm{Co} 2$ and $\mathrm{Co} 7$ as a monoatomic bridge. All cobalt centers are found in the 2+ oxidation state, as evidenced by their bond distances, as well as BVS calculations (BVS values ranging from 1.76-2.03), and are found in an octahedral geometry adopting cis- $\mathrm{O}_{4} \mathrm{~N}_{2}$ (Co1, Co2, $\mathrm{Co} 4$ ), cis- $\mathrm{O}_{2} \mathrm{~N}_{4}$ (Co6, Co3), $\mathrm{O}_{5} \mathrm{~N}(\mathrm{Co} 5)$ and $\mathrm{O}_{6}(\mathrm{Co} 7)$ coordination environment.

Cluster 3 also crystallizes in the triclinic $P \overline{1}$ space group; its metallic core consists of ten edge-sharing $\left[\mathrm{Co}_{3}\right]$ triangles, forming a slightly bent $\left[\mathrm{Co}_{10}\right]$ disc (Fig. 3) with dimensions of $\sim 10 \times 6 \AA$. The ten metallic centers are held in position by fourteen monoanionic $\mathrm{L}^{-}$ligands which adopt six different coordination modes: (i) five are found in mode B, (ii) three in mode $\mathrm{F}$ in which the $\mathrm{O}_{\text {oximate }}$ forms a six-member chelate ring with the $\mathrm{N}_{\text {aromatic }}$ and further bridges to two cobalt centers, (iii) two in mode $\mathrm{D}$, (iv) one in mode $\mathrm{G}$, (v) one in mode $\mathrm{C}$, according to which the $\mathrm{O}_{\text {oximate }}$ forms a six-member ring with the $\mathrm{N}_{\text {aromatic }}$ and further bridges to one metallic center, and (vi) two in mode A. In addition, the coordination environment of the metallic centers is completed by the presence of three $\mu_{3}-\mathrm{OH}^{-}$and one $\mu-$ $\mathrm{OH}^{-}$. Co5, $\mathrm{Co} 8$ and $\mathrm{Co} 7$ are five-coordinate adopting distorted tetragonal pyramidal for the former two centers and highly distorted trigonal bipyramidal geometry for the remaining center, with $\tau$ values of $0.26,0.30$ and 0.62 respectively, while all remaining centers are six-coordinate adopting octahedral geometry. ${ }^{9}$ Furthermore, the coordination spheres of the metallic centers are $\mathrm{O}_{6}(\mathrm{Co} 1), \mathrm{O}_{5} \mathrm{~N}(\mathrm{Co} 2, \mathrm{Co} 9)$, cis $-\mathrm{O}_{2} \mathrm{~N}_{4}(\mathrm{Co} 3$, Co4, Co6) and $f a c-\mathrm{O}_{3} \mathrm{~N}_{3}$ (Co10) sphere. Finally, all metallic centers are in the $2+$ oxidation state, as derived from BVS calculations yielding values in the 1.77-2.04 range.

Complex 4 (Fig. 4) crystallizes in the monoclinic space group $C 2 / c$ in special position of $C_{2}$ symmetry; its metallic core describes a tetrahedron of four $\mathrm{Co}^{2+}$ ions linked together by (i) four fully deprotonated $\mathrm{L}^{-}$ligands in mode $\mathrm{A}$, forming a distorted $\left[\mathrm{Co}_{4}(\mathrm{NO})_{4}\right]^{4+}$ cube comprising alternate single $(\mathrm{O})$ and double $(\mathrm{N}-\mathrm{O})$ atom edges, and (ii) two $\eta^{1}: \eta^{1}: \mu$ pivalate ligands. Finally, two terminal pivalate ligands and two methanol molecules complete the coordination environment of the metal centers. The dimensions of the metallic tetrahedron are in the range 3.09-4.43 $\mathrm{A}$ with the shortest distance between Co1 and $\mathrm{Co} 2$, and the longest between Co1 and Co1'. All metals are found in the 2+ oxidation state (BVS values: 2.16 for Co1 and 2.17 for Co2, Fig. 4), and are six-coordinate.

The mononuclear complex 5 crystallizes in the monoclinic $P 2_{1} / c$ space group. Its structure (Fig. 5) consists of a central $\mathrm{Co}^{3+}$ ion coordinated by one chelate $\mathrm{L}^{-}$ligand via its oximate and one

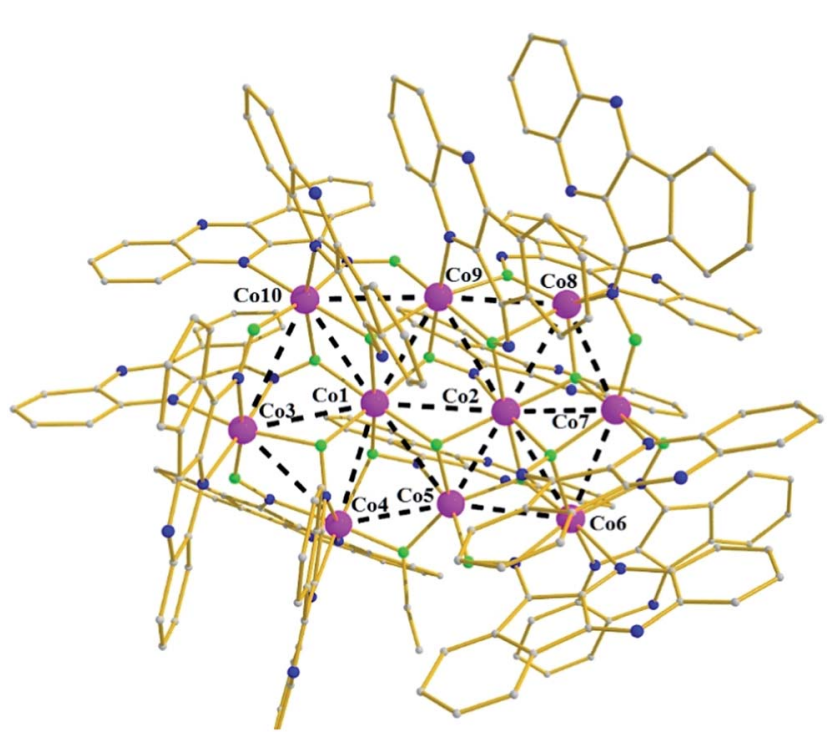

Fig. 3 Molecular structure of the cationic part of 3. Color code: same as in Fig. 1. Disorder and $\mathrm{H}$ atoms as well as solvent molecules not shown for clarity. 


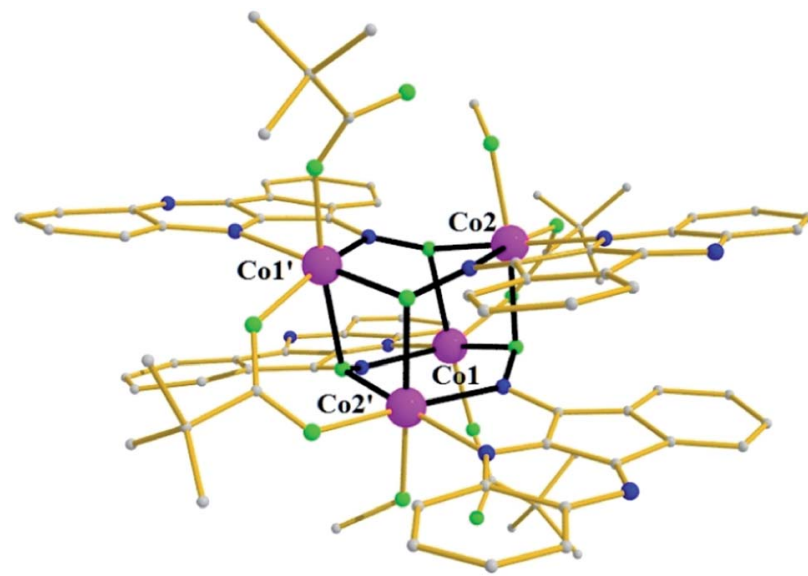

Fig. 4 The molecular structure of cluster 4, highlighting its cube-like core. Color code: same as in Fig. 1. Disorder and $\mathrm{H}$ atoms not shown for clarity. Symmetry code: ' $=-x+1, y,-z+1 / 2$.

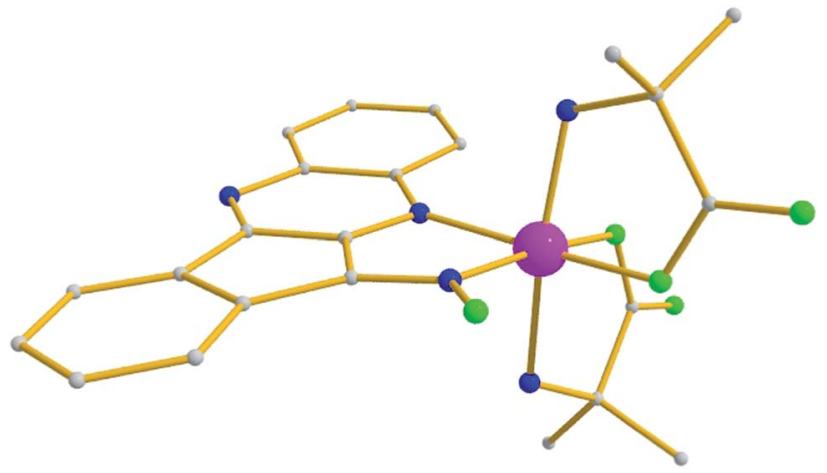

Fig. 5 Molecular structure of complex 5. Color code: same as in Fig. 1. Disorder and $\mathrm{H}$ atoms as well as solvent molecules not shown for clarity.

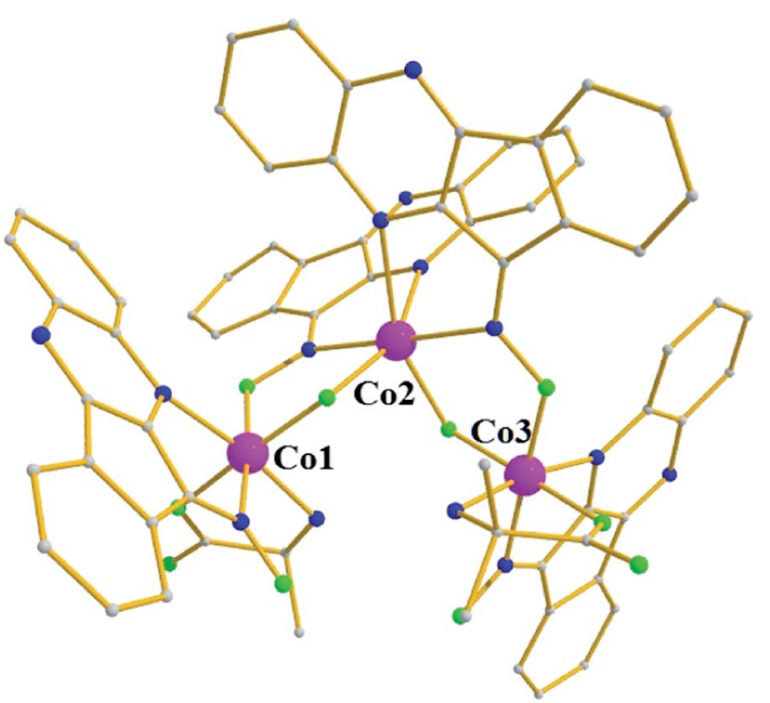

Fig. 6 Molecular structure of complex 6. Color code: same as in Fig. 1. Disorder and $\mathrm{H}$ atoms not shown for clarity. aromatic $\mathrm{N}$ atoms (mode $\mathrm{E}$ ), and two $\mathrm{aib}^{-}$ligands in a chelate mode, thus forming three five-member chelate rings. The metal ion is found in a cis- $\mathrm{O}_{2} \mathrm{~N}_{4}$ sphere, while BVS calculations yielded a value of 3.11 for the central metal atom.

Complex 6 crystallizes in the monoclinic space group $P 2_{1} / n$. The structure consists of a trimetallic unit with a "V-shape" arrangement of the three metallic centers (Fig. 6), which are held together by two deprotonated ligands, $\mathrm{L}^{-}$, found in mode $\mathrm{B}$, and two $\mu-\mathrm{OH}^{-}$groups. Each terminal metallic atom is further coordinated to a deprotonated chelate $\mathrm{L}^{-}$ligand (mode E) and to one chelate aib $^{-}$ligand. The formula of the complex necessitates a mixed-valent $\mathrm{Co}_{2}{ }_{2} \mathrm{Co}^{\mathrm{II}}$ oxidation state, and according to BVS calculations the two terminal cobalt atoms are in the 3+ oxidation state (BVS values of 3.15 and 3.22 for Co1 and Co3, respectively), while the central one in the $2+$ (BVS value: 2.01$)$. All metallic centers are six-coordinate adopting

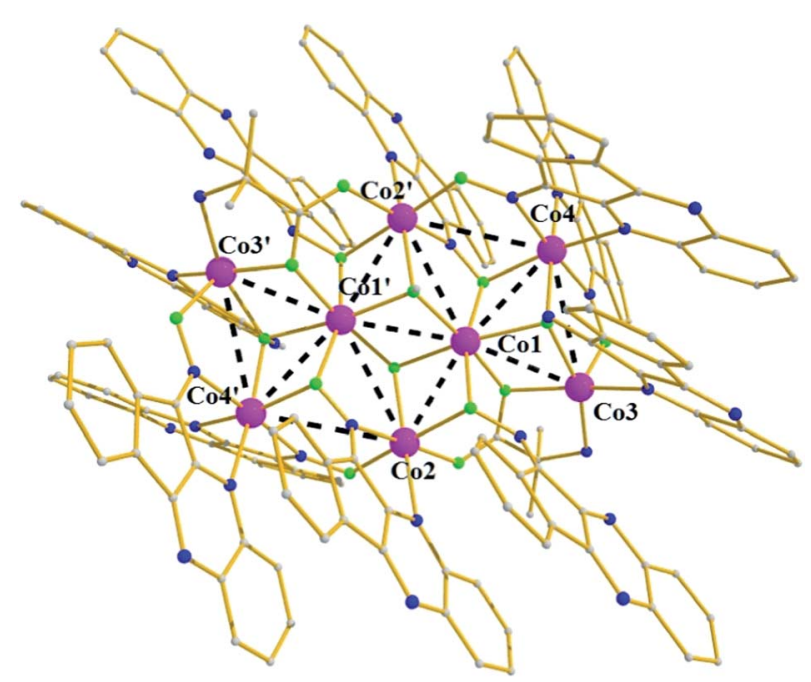

Fig. 7 Molecular structure of the cationic part of complex 7. Color code: same as in Fig. 1. $\mathrm{H}$ atoms and solvent molecules not shown for clarity. Symmetry code ' $=-x+1,-y+1,-z+1$.

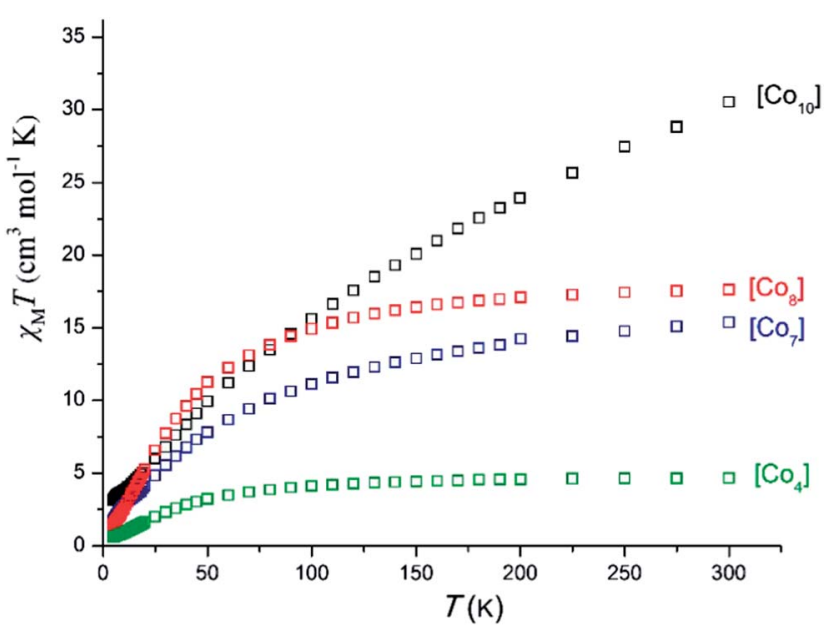

Fig. 8 Plot of $\chi_{M} T$ vs. $T$ for complexes $2\left(\left[\mathrm{CO}_{7}\right]\right), 3\left(\left[\mathrm{CO}_{10}\right]\right), 4\left(\left[\mathrm{CO}_{4}\right]\right)$ and $7\left(\left[\mathrm{CO}_{8}\right]\right)$ under an applied dc field of $1000 \mathrm{G}$. 


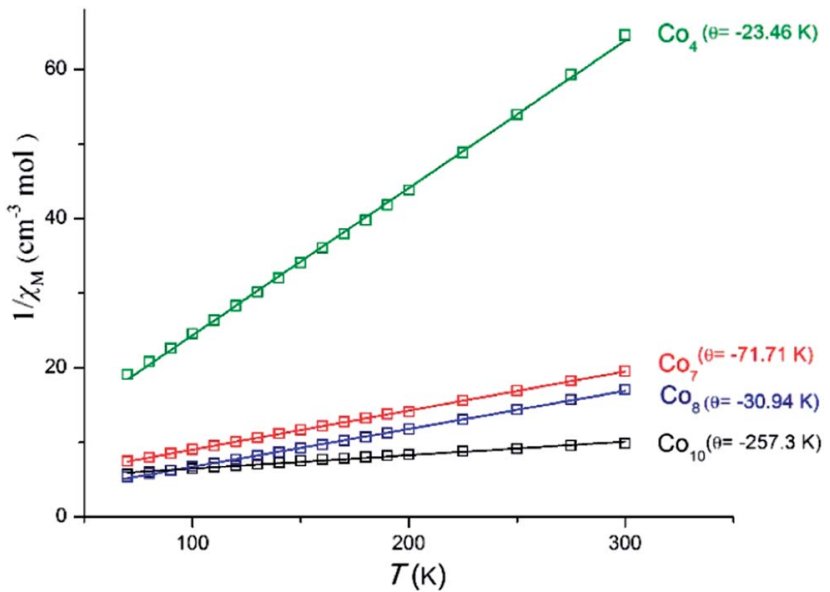

Fig. 9 Curie-Weiss plot for complexes 2, 3, 4 and 7 in the 50-300 K range.

octahedral geometry, with Co1 and Co3 in a $m e r-\mathrm{O}_{3} \mathrm{~N}_{3}$ coordination sphere, and $\mathrm{Co} 2$ in a cis- $\mathrm{O}_{4} \mathrm{~N}_{2}$ arrangement.

Finally, complex 7 crystallizes in the triclinic $P \overline{1}$ space group in special position - center of symmetry. Its metallic core (Fig. 7) consists of a planar octametallic disk, in which the eight metallic centers are held in position by ten deprotonated, $\mathrm{L}^{-}$, ligands adopting four different coordination modes; (i) two in mode A, (ii) four in mode B, (iii) two in a monoatomic bridge fashion via the $\mathrm{O}_{\text {oximate }}$, mode $\mathrm{H}$, and (iv) two in mode $\mathrm{F}$. In addition, two deprotonated $\mathrm{aib}^{-}$ligands are present in an $\eta^{2}: \eta^{1}: \eta^{1}: \mu_{3}$ fashion, while two $\mu_{3}{ }^{-} \mathrm{OCH}_{3}{ }^{-}$groups complete the coordination environment of the octametallic disc. All cobalt atoms are six-coordinate, besides $\mathrm{Co} 3$ (and its symmetry related $\mathrm{Co3}^{\prime}$ ) which is five coordinate adopting tetragonal pyramidal $(\tau \approx 0)$. Finally, all cobalt centers are in the $2+$ oxidation state, as evidenced by BVS calculations giving values in the 1.75-2.01 range.

\section{Magnetochemistry}

Dc magnetic susceptibility studies. Direct current magnetic susceptibility studies were performed on polycrystalline samples of 2, 3, 4 and 7 in the 5-300 $\mathrm{K}$ range under an applied field of $0.1 \mathrm{~T}$. The results are plotted as the $\chi_{\mathrm{M}} T$ product $\nu s . T$ in Fig. 8. Given the presence of octahedral $\mathrm{Co}^{\mathrm{II}}$ ions with ${ }^{4} \mathrm{~T}_{1 g}$ ground term, that splits to a doublet ground-state at low temperature when in distorted environment due to spin-orbit coupling, ${ }^{10}$ it is very laborious and extremely difficult to apply an exact theoretical model for fitting the magnetic susceptibility data. ${ }^{11}$ Furthermore, Co(II) ions when in octahedral geometry may be treated as pseudo " $S_{\text {eff }}=1 / 2$ " systems at low

Table 1 Structurally characterized heptanuclear cobalt $\left[\mathrm{CO}_{7}\right]$ clusters $^{a}$

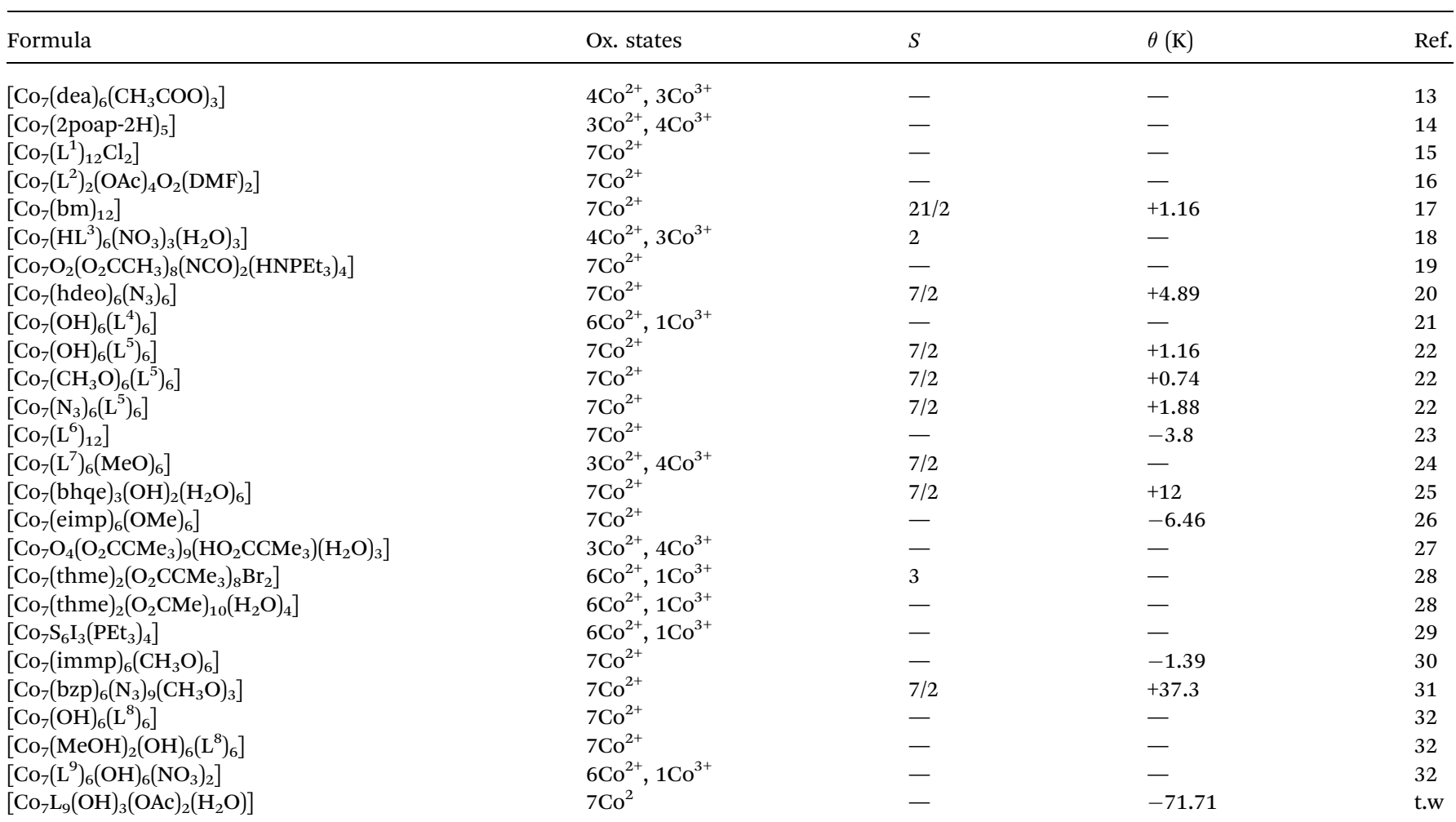

${ }^{a} \mathrm{H}_{2}$ dea = diethanolamine; poap: tritopic pyridine dihydazone ligand; $\mathrm{HL}^{1}$ : pyridine-2-ylmethanol; $\mathrm{H}_{3} \mathrm{~L}^{2}$ : tris[3,5-bis(methyl)-benzoic acid]cyclotricatechylene; $\mathrm{Hbm}=\left(1 \mathrm{H}\right.$-benzimidazol)-methanol; $\mathrm{H}_{3} \mathrm{~L}^{3}=\mathrm{H}_{2} \mathrm{NC}\left(\mathrm{CH}_{2} \mathrm{OH}\right)_{3}$; Hhdeo = 2-hydroxy-[1,2-di (pyridin-2-yl)]ethane-1-one; $\left(\mathrm{L}^{4}\right)^{-}$ is the anion of 2-(pyridine-2-yl)pentane-2-ol-4-one; $\mathrm{HL}^{5}$ : 2-methoxy-6-[(methylimino)-methyl]phenol; $\mathrm{HL}^{6}$ : 6-methyl-2-pyridone; $\mathrm{H}_{2} \mathrm{~L}^{7}$ : $1,1,1-$ trifluoro-7-hydroxy-4-methyl-5-aza-hept-3-en-2-one; $\mathrm{H}_{4}$ bhqe: 1,2-bis(8-hydroxyquinolin-2-yl)ethane-1,2-diol; Heimp: 2-ethoxy-6-(iminomethyl)phenol; $\mathrm{H}_{3}$ thme: 1,1,1-tris(hydroxymethyl)ethane; Immp: 2-iminomethyl-6-methoxy-phenolic anion; bzp $=2$-benzoyl pyridine; $\mathrm{HL}^{8}=2$ iminomethyl-6-methoxyphenol; $\mathrm{HL}^{9}=2$-iminophenyl-6-methoxyphenol. 
Table 2 Structurally characterized octanuclear cobalt $\left[\mathrm{Co}_{8}\right]$ clusters $^{a}$

\begin{tabular}{|c|c|c|c|c|}
\hline Formula & Ox. states & $S$ & $\theta(\mathrm{K})$ & Ref. \\
\hline$\left[\mathrm{Co}_{8} \mathrm{~S}_{6}(\mathrm{SPh})_{8}\right]$ & $4 \mathrm{Co}^{2+}, 4 \mathrm{Co}^{3+}$ & - & - & 33 \\
\hline$\left[\mathrm{Co}_{8}(\mathrm{NPh})_{9}\left(\mathrm{PPh}_{3}\right)_{2}\right]$ & $7 \mathrm{Co}^{2+}, 1 \mathrm{Co}^{3+}$ & - & - & 34 \\
\hline$\left[\mathrm{Co}_{8}\left(\mathrm{~L}^{1}\right)_{4}(\mathrm{OH})_{2}\left(\mathrm{H}_{2} \mathrm{O}\right)_{4}\left(\mathrm{NO}_{3}\right)_{2}(\mathrm{bpy})_{4}\right]$ & $8 \mathrm{Co}^{2+}$ & - & - & 36 \\
\hline$\left[\mathrm{Co}_{8} \mathrm{OQ}_{12}\right]$ & $8 \mathrm{Co}^{2+}$ & - & -59 & 37 \\
\hline$\left(\mathrm{PPh}_{4}\right)\left[\mathrm{Co}_{8} \mathrm{~S}_{6} \mathrm{Br}_{2} \mathrm{Cl}_{2}\left(\mathrm{PPh}_{3}\right)_{4}\right]$ & $1 \mathrm{Co}^{1+}, 7 \mathrm{Co}^{2+}$ & - & - & 38 \\
\hline$\left[\mathrm{Co}_{8} \mathrm{O}_{2}\left(\mathrm{O}_{2} \mathrm{CN}^{\mathrm{i}} \mathrm{Pr}_{2}\right)_{12}\right]$ & $8 \mathrm{Co}^{2+}$ & - & - & 41 \\
\hline$\left[\mathrm{Co}_{8}\left(\mathrm{MeCO}_{2}\right)_{8}(\mathrm{OMe})_{16}\right]$ & $8 \mathrm{Co}^{3+}$ & - & - & 42 \\
\hline$\left[\mathrm{Co}_{8} \mathrm{O}_{4}\left(\mathrm{CH}_{3} \mathrm{CO}_{2}\right)_{6}(\mathrm{OMe})_{4}\right] \mathrm{Cl}_{4}\left(\mathrm{OH}_{2}\right)_{4}$ & $2 \mathrm{Co}^{2+}, 6 \mathrm{Co}^{3+}$ & & & 43 \\
\hline$\left[\mathrm{Co}_{8}(\mathrm{chp})_{10}\left(\mathrm{O}_{3} \mathrm{PPh}\right)_{2}\left(\mathrm{NO}_{3}\right)_{3}(\mathrm{Hchp})_{2}\right]$ & $8 \mathrm{Co}^{2+}$ & - & - & 44 \\
\hline$\left[\mathrm{Co}_{8}(\mathrm{IBT})_{12}\right]^{14-}$ & $2 \mathrm{Co}^{2+}, 6 \mathrm{Co}^{3+}$ & - & - & 45 \\
\hline$\left[\mathrm{Co}_{8}\left(\mathrm{~L}^{4}\right)_{4}(\mathrm{OH})_{4}(\mathrm{MeOH})_{16}\right]$ & $8 \mathrm{Co}^{2+}$ & $3 / 2$ & - & 46 \\
\hline$\left[\mathrm{Co}_{8} \mathrm{O}_{2}\left(\mathrm{OOCCMe}_{3}\right)_{12}\right](n: 2$ or 3$)$ & $8 \mathrm{Co}^{2+}$ & - & - & 51 and 52 \\
\hline$\left[\mathrm{Co}_{8}^{\mathrm{II}} \mathrm{L}_{10}(\mathrm{aib})_{2}(\mathrm{MeO})_{2}\right]\left(\mathrm{ClO}_{4}\right)_{2}$ & $8 \mathrm{Co}^{2}$ & & -30.9 & t.w. \\
\hline
\end{tabular}

${ }^{a} \mathrm{H}_{2} \mathrm{~L}^{1}$ : 1,3-bis-(3-oxo-3-(2-pyridyl)-propionyl)-pyridine; HQ: 8-hydroxyquinoline; $\mathrm{L}^{2}$ : modified 2,4,4,5,5-pentamethyl-4,5-dihydro-1H-imidazole-(3oxide)-1-oxyl; $\mathrm{L}^{3}$ : 2,2'-biphenol, 2-hpH: 2-hydroxypyridine; Hchp: 6-chloro-2-hydroxypyridine; $\mathrm{H}_{3} \mathrm{IBT}$ : 4,5-bis(tetrazol-5yl)imidazole; $\mathrm{H}_{2} \mathrm{~L}^{4}$ : 2,6 -bis[5-(2-pyridinyl)-1H-pyrazole-3-yl] pyridine; chp = 6-chloro-2-pyridonate; $\mathrm{H}_{4} \mathrm{TC} 4 \mathrm{~A}$ : p-tert-butylthiacalix[4]arene; $\mathrm{H}_{4} \mathrm{~L}^{5}$ : 3-hydroxysalamo; $\mathrm{L}^{6}$ : bisbidentate ligand.

Table 3 Structurally characterized decanuclear cobalt $\left[\mathrm{Co}_{10}\right]$ clusters $^{a}$

\begin{tabular}{|c|c|c|c|c|}
\hline Formula & Ox. st. & $S$ & $\theta(\mathrm{K})$ & Ref. \\
\hline$\left[\mathrm{Co}_{10}(\mathrm{Q})_{12}\left(\mathrm{CO}_{3}\right)_{4}\right]$ & $10 \mathrm{Co}^{2+}$ & - & -21.1 & 12 \\
\hline$\left[\mathrm{Co}_{10}(\mathrm{OH})_{6}(\mathrm{chp})_{6}(o-\mathrm{MeBz})_{7}\left(n-\mathrm{C}_{3} \mathrm{H}_{7} \mathrm{OH}\right)_{5}\right][o-\mathrm{MeBz}]$ & $10 \mathrm{Co}^{2+}$ & - & - & 53 \\
\hline$\left[\mathrm{Co}_{10}(\mathrm{OH})_{6}(\mathrm{mhp})_{6}\left(\mathrm{O}_{2} \mathrm{CPh}\right)_{7}(\mathrm{Hmhp})_{3} \mathrm{Cl}(\mathrm{MeCN})\right]$ & $10 \mathrm{Co}^{2+}$ & - & - & 54 \\
\hline$\left[\mathrm{Co}_{10}(\mathrm{OH})_{6}(\mathrm{mhp})_{6}\left(\mathrm{O}_{2} \mathrm{CCMe}_{3}\right)_{7} \mathrm{Cl}(\mathrm{MeCN})_{3}(\mathrm{Hmhp})\right]$ & $10 \mathrm{Co}^{2+}$ & - & - & 54 \\
\hline$\left[\mathrm{Co}_{10}(\mathrm{OH})_{4}(\mathrm{chp})_{10}\left(\mathrm{O}_{2} \mathrm{CCMe}_{3}\right)_{6}(\mathrm{EtOH})_{2}\right]$ & $10 \mathrm{Co}^{2+}$ & - & - & 54 \\
\hline$\left[\mathrm{Co}_{10} \mathrm{O}(\mathrm{OH})(\mathrm{dpm})_{4}(\mathrm{cht})_{2}(\mathrm{Hcht})_{2}\left(\mathrm{AdCO}_{2}\right)_{3}(\mathrm{EtOH})_{3}\right]$ & $10 \mathrm{Co}^{2+}$ & - & - & 12 \\
\hline$\left[\mathrm{Co}_{10}(\mathrm{OH})_{6}(\mathrm{mhp})_{6}\left(\mathrm{O}_{2} \mathrm{CCPh}_{3}\right)_{6}(\mathrm{Hmhp})_{3}\left(\mathrm{HCO}_{3}\right)_{3}\right]$ & $9 \mathrm{Co}^{2+}, 1 \mathrm{Co}^{3+}$ & - & - & 56 \\
\hline$\left[\mathrm{Co}_{10}(\mathrm{OH})_{2}(\mathrm{chp})_{14}\left(\mathrm{O}_{3} \mathrm{PCH}_{2} \mathrm{CH}_{2} \mathrm{PO}_{3}\right)\right]$ & $10 \mathrm{Co}^{2+}$ & - & - & 57 \\
\hline$\left[\mathrm{Co}(\mathrm{OH})\left(4-\mathrm{NO}_{2}-\mathrm{pz}\right)\left(3,5-\mathrm{Me}_{2}-\mathrm{pz}\right)\right]_{10}$ & $10 \mathrm{Co}^{3+}$ & - & - & 58 \\
\hline$\left[\mathrm{Co}_{10}(\mathrm{chp})_{12}\left(\mathrm{O}_{3} \mathrm{PPh}\right)_{2}\left(\mathrm{O}_{2} \mathrm{CPh}\right)_{4}\left(\mathrm{H}_{2} \mathrm{O}\right)_{4}\right]$ & $10 \mathrm{Co}^{2+}$ & - & - & 59 \\
\hline$\left[\mathrm{Co}_{10}(\mathrm{chp})_{12}\left(\mathrm{O}_{3} \mathrm{PPh}\right)_{2}\left(\mathrm{O}_{2} \mathrm{C}^{\mathrm{t}} \mathrm{Bu}\right)_{4}\left(\mathrm{H}_{2} \mathrm{O}\right)_{4}\right]$ & $10 \mathrm{Co}^{2+}$ & - & - & 59 \\
\hline$\left[\mathrm{Co}_{10}(\mathrm{chp})_{8}\left(\mathrm{O}_{3} \mathrm{PCH}_{2} \mathrm{Ph}\right)_{2}\left(\mathrm{O}_{2} \mathrm{CPh}\right)_{8}(\mathrm{~F})_{2}(\mathrm{MeCN})_{2}\right]$ & $10 \mathrm{Co}^{2+}$ & - & - & 59 \\
\hline$\left[\mathrm{Co}_{10}(\mathrm{chp})_{6}\left(\mathrm{O}_{3} \mathrm{PCH}_{2} \mathrm{Ph}\right)_{2}\left(\mathrm{O}_{2} \mathrm{C}{ }^{t} \mathrm{Bu}\right)_{8}(\mathrm{~F})_{2}\left(\mathrm{H}_{2} \mathrm{O}\right)_{2}\right]$ & $10 \mathrm{Co}^{2+}$ & - & - & 59 \\
\hline$\left[\mathrm{Co}_{10}(\mathrm{chp})_{6}\left(\mathrm{O}_{3} \mathrm{PMe}\right)_{2}\left(\mathrm{O}_{2} \mathrm{C}^{t} \mathrm{Bu}\right)_{8}(\mathrm{~F})_{2}(\mathrm{MeCN})_{4}\right]$ & $10 \mathrm{Co}^{2+}$ & - & - & 59 \\
\hline$\left[\mathrm{Co}_{10}(\mathrm{chp})_{6}\left(\mathrm{O}_{3} \mathrm{PEt}\right)_{2}\left(\mathrm{O}_{2} \mathrm{CPh}\right)_{8}(\mathrm{~F})_{2}(\mathrm{MeCN})_{4}\right]$ & $10 \mathrm{Co}^{2+}$ & - & - & 59 \\
\hline$\left[\mathrm{Co}_{10}(\mathrm{chp})_{6}\left(\mathrm{O}_{3} \mathrm{POct}\right)_{2}\left(\mathrm{O}_{2} \mathrm{CPh}\right)_{8}(\mathrm{~F})_{2}(\mathrm{MeCN})_{4}\right]$ & $10 \mathrm{Co}^{2+}$ & - & - & 59 \\
\hline$\left[\mathrm{Co}_{10}(\mathrm{chp})_{8}(\mathrm{Hchp})_{2}\left(\mathrm{O}_{3} \mathrm{PCH}_{2} \mathrm{Nap}\right)\left(\mathrm{O}_{2} \mathrm{CPh}\right)_{7}(\mathrm{OH})_{3}\right]$ & $10 \mathrm{Co}^{2+}$ & - & - & 59 \\
\hline$\left[\mathrm{Co}_{10} \mathrm{~L}_{14}(\mathrm{OH})_{3}(\mathrm{MeO})\right]\left(\mathrm{ClO}_{4}\right)_{2}$ & $10 \mathrm{Co}^{2+}$ & - & -257 & t.w \\
\hline
\end{tabular}

${ }^{a}$ Q: 8-hydroxyquinoline, chp: 2-chloro-6-pyridonate, o-MeBz = 2-methylbenzoate, mhp: 2-methyl-6-pyridonate, Hmhp: 2-methyl-6-hydroxypyridine, p-tBuBz: 4-tertbutylbenzoate, Piv: $\left(\mathrm{CH}_{3}\right)_{3} \mathrm{CCO}_{2}{ }^{-}, \mathrm{L}^{2} \mathrm{~L}^{3}$ : modified molecules of the starting NIT-Me (2,4,4,5,5-pentamethyl-4,5-dihydro-1 $\mathrm{H}$-imidazole3-oxide-1-oxyl) and/or Im-Me (2,4,4,5,5-pentamethyl-4,5-dihydro- $1 H$-imidazole-1-oxyl), Hdpm: dipivaloylmethane, $\mathrm{H}_{3}$ tmp: $[1,1,1$-tris(hydroxymethyl) propane, $\left.\mathrm{EtC}\left(\mathrm{CH}_{2} \mathrm{OH}\right)_{3}\right], \mathrm{AdCO}_{2} \mathrm{H}$ : adamantyl carboxylic acid, $\mathrm{H}_{3}$ cht: cis, cis-1,3,5-cyclohexanetriol, mhp: 6-methyl-2-pyridonate, Hchp: 6-chloro-2hydroxypyridine, $\mathrm{O}_{2} \mathrm{C}^{t} \mathrm{Bu}$ : pivalate, $\mathrm{O}_{2} \mathrm{CPh}^{t} \mathrm{Bu}$ : 4-tert-butylbenzoic acid, $\mathrm{O}_{2} \mathrm{CPh}$-2-Ph: 2-biphenylcarboxylic acid. 
temperature due to the splitting of the Kramers doublets. Therefore, we feel it is prudent to attempt only a qualitative analysis of the data, in order to avoid misinterpretation of the magnetic data.

For complex $2\left(\left[\mathrm{Co}_{7}\right]\right)$ the room temperature $\chi_{\mathrm{M}} T$ value of $15.39 \mathrm{~cm}^{3} \mathrm{~K} \mathrm{~mol}^{-1}$ corresponds to seven non-interacting $\mathrm{Co}^{\mathrm{II}}$ ions with $S=3 / 2$ and $g=2.17$. Upon cooling the $\chi_{\mathrm{M}} T$ value decreases to reach a minimum value of $1.70 \mathrm{~cm}^{3} \mathrm{~K} \mathrm{~mol}^{-1}$ at $5 \mathrm{~K}$, suggesting the presence of dominant antiferromagnetic interactions. For cluster $4\left(\left[\mathrm{Co}_{4}\right]\right)$ the room temperature $\chi_{\mathrm{M}} T$ value of $4.64 \mathrm{~cm}^{3} \mathrm{~K} \mathrm{~mol}^{-1}$ is very close to the spin-only value of 4.411 $\mathrm{cm}^{3} \mathrm{~K} \mathrm{~mol}^{-1}$ corresponding to two non-interacting $\mathrm{Co}^{\mathrm{II}}$ ions. Upon cooling, this value remains constant until $\sim 90 \mathrm{~K}$, before it decreases to reach the minimum value of $0.62 \mathrm{~cm}^{3} \mathrm{~K} \mathrm{~mol}^{-1}$ at 5 $\mathrm{K}$, with this behavior suggesting the presence of dominant, albeit weak, antiferromagnetic interactions. A similar behavior is encountered for cluster $7\left(\left[\mathrm{Co}_{8}\right]\right)$; the room temperature $\chi_{\mathrm{M}} T$ value of $17.61 \mathrm{~cm}^{3} \mathrm{~K} \mathrm{~mol}^{-1}$ is very close to the spin-only value of $17.65 \mathrm{~cm}^{3} \mathrm{~K} \mathrm{~mol}^{-1}$ corresponding to eight non-interacting $\mathrm{Co}^{\mathrm{II}}$ ions. Upon cooling, this value remains constant until $\sim 120 \mathrm{~K}$, below which it decreases to reach the minimum value of 1.43 $\mathrm{cm}^{3} \mathrm{~K} \mathrm{~mol}^{-1}$ at $5 \mathrm{~K}$.

On the other hand, cluster $3\left(\left[\mathrm{Co}_{10}\right]\right)$ displays different behavior than the three complexes already mentioned; the room temperature $\chi_{\mathrm{M}} T$ value of $30.51 \mathrm{~cm}^{3} \mathrm{~K} \mathrm{~mol}^{-1}$ is larger than the expected value for ten non-interacting $S=3 / 2$ ions of 18.7 $\mathrm{cm}^{3} \mathrm{~K} \mathrm{~mol}^{-1}$ (for $g=2$ ), suggesting the presence of significant orbital contribution, as has been previously reported for other $\left[\mathrm{Co}^{\mathrm{II}}{ }_{10}\right]$ clusters. ${ }^{12}$ Upon cooling the $\chi_{\mathrm{M}} T$ value decreases rapidly to reach the minimum value of $3.12 \mathrm{~cm}^{3} \mathrm{~K} \mathrm{~mol}^{-1}$, suggesting the presence of dominant and strong antiferromagnetic interactions.

The presence of the antiferromagnetic interactions in all complexes was further established by Curie-Weiss analysis of the high temperature $(50-300 \mathrm{~K})$ magnetic susceptibility data (Fig. 9), yielding negative $\theta$ values for all of them.

Complex 2 joins a small family of twenty six structurally characterized heptanuclear clusters (Table 1), in various oxidation states, while complexes 7 and $\mathbf{3}$ join a family of structurally characterized octanuclear and decanuclear cobalt clusters, respectively, in which the vast majority consists exclusively of divalent metal atoms (Tables 2 and 3 ).

Complexes 2, 3, 4 and 7 were also studied by alternating current ac magnetic susceptibility studies as a means of investigating potential single molecule magnetism behavior, but no out-of-phase signals were observed, thus ruling out this possibility.

\section{Conclusions}

In conclusion, we have reported the syntheses, structures and magnetic properties of seven new Co complexes stabilized by an indeno-quinoxaline based oxime ligand, LH. Following our initial results on nickel cluster chemistry, we have now found that this ligand can lead to the synthesis of cobalt clusters, as well. More importantly, the ligand adopts eight different coordination modes leading to clusters with various nuclearities.
Studies are underway for the employment of the ligand in $3 \mathrm{~d}-4 \mathrm{f}$ and $4 \mathrm{f}$ chemistry, and the findings will be reported in the future.

\section{Acknowledgements}

CJM would like to thank The Excellence Grant (ARISTEIA-2691) for funding. DIT would like to thank the 89439/2012 Grant of the Aristotle University of Thessaloniki.

\section{Notes and references}

1 See for example: P. Chaudhuri, Coord. Chem. Rev., 2003, 243, 143; C. J. Milios, T. C. Stamatatos and S. P. Perlepes, Polyhedron, 2006, 35, 134-194; A. G. Smith, P. A. Tasker and D. J. White, Coord. Chem. Rev., 2003, 241, 61; M. Viciano-Chumillas, S. Tanase, I. Mutikainen, U. Turpeinen, L. J. de Jongh and J. Reedijk, Inorg. Chem., 2008, 47, 5919; P. Chaudhuri, M. Hess, E. Rentschler, T. Weyhermüller and U. Flörke, New J. Chem., 1998, 22, 553; P. Chaudhuri, M. Hess, T. Weyhermüller, E. Bill, H.-J. Haupt and U. Flörke, Inorg. Chem. Commun., 1998, 1, 39; P. Chaudhuri, M. Winter, U. Flörke and H.-J. Haupt, Inorg. Chim. Acta, 1995, 232, 125; S. Ross, T. Weyhermüller, E. Bill, K. Wieghardt and P. Chaudhuri, Inorg. Chem., 2001, 40, 6656; D. Burdinski, F. Birkelbach, T. Weyhermüller, U. Flörke, H.-J. Haupt, M. Lengen, A. X. Trautwein, E. Bill, K. Wieghardt and P. Chaudhuri, Inorg. Chem., 1998, 37, 1009. 2 Representative refs and refs therein: C. J. Milios, C. P. Raptopoulou, A. Terzis, F. Lloret, R. Vicente, S. P. Perlepes and A. Escuer, Angew. Chem., Int. Ed., 2004, 43, 210; T. C. Stamatatos, D. Foguet-Albiol, C. C. Stoumpos, C. P. Raptopoulou, A. Terzis, W. Wernsdorfer, S. P. Perlepes and G. Christou, J. Am. Chem. Soc., 2005, 127, 15380; C. J. Milios, R. Inglis, A. Vinslava, A. Prescimone, S. Parsons, W. Wernsdorfer, S. P. Perlepes, G. Christou and E. K. Brechin, Chem. Commun., 2007, 2738; C. J. Milios, R. Inglis, L. F. Jones, A. Prescimone, S. Parsons, W. Wernsdorfer and E. K. Brechin, Dalton Trans., 2009, 2812-2822; C. J. Milios, S. Piligkos and E. K. Brechin, Dalton Trans., 2008, 1809.

3 See for example: A. Chakravorty, Coord. Chem. Rev., 1974, 13, 1; J. A. Bertrand and P. G. Eller, Prog. Inorg. Chem., 1976, 21, 29; A. G. Smith, P. A. Tasker and D. J. White, Coord. Chem. Rev., 2003, 241, 61; V. Y. Kukushkin, D. Tudela and A. J. L. Pombeiro, Coord. Chem. Rev., 1996, 156, 333; V. Y. Kukushkin and A. J. L. Pombeiro, Coord. Chem. Rev., 1999, 181, 147; A. J. L. Pombeiro and V. Y. Kukushkin, in Comprehensive Coordination Chemistry II, ed. J. A. McCleverty and T. C. Meyer, Elsevier, Amsterdam, 2004, vol. 1, p. 631; K. F. Konidaris, V. Bekiari, E. Katsoulakou, C. P. Raptopoulou, V. Psycharis, S. P. Perlepes, T. C. Stamatatos and E. M. Zoupa, Inorg. Chim. Acta, 2011, 376, 470; C. Papatriantafyllopoulou, M. Estrader, C. G. Efthymiou, D. Dermitzaki, K. Gkotsis, A. Terzis, C. Diaz and S. P. Perlepes, Polyhedron, 2009, 28, 1652; T. C. Stamatatos, E. Katsoulakou, A. Terzis, C. P. Raptopoulou, R. E. P. Winpenny and S. P. Perlepes, 
Polyhedron, 2009, 28, 1638; C. G. Efthymiou, C. P. Raptopoulou, A. Terzis, S. P. Perlepes, A. Escuer and C. Papatriantafyllopoulou, Polyhedron, 2010, 29, 627; C. Papatriantafyllopoulou, G. Aromi, A. J. Tasiopoulos, V. Nastopoulos, C. P. Raptopoulou, S. J. Teat, A. Escuer and S. P. Perlepes, Eur. J. Inorg. Chem., 2007, 2761; E. Moushi, C. G. Efthymiou, S. P. Perlepes and C. Papatriantafyllopoulou, Int. J. Inorg. Chem., 2011, 606271; C. Papatriantafyllopoulou, L. F. Jones, T. D. Nguyen, N. Matamoros-Salvador, L. Cunha-Silva, F. A. A. Paz, J. Rocha, M. Evangelisti, E. K. Brechin and S. P. Perlepes, Dalton Trans., 2008, 3153; G. C. Vlahopoulou, T. C. Stamatatos, V. Psycharis, S. P. Perlepes and G. Christou, Dalton Trans., 2009, 3647; A. Escuer, G. Vlahopoulou, S. P. Perlepes, M. Font-Bardia and T. Calvet, Dalton Trans., 2011, 40, 225; T. C. Stamatatos, E. Diamantopoulou, C. P. Raptopoulou, V. Psycharis, A. Escuer and S. P. Perlepes, Inorg. Chem., 2007, 46, 2350; C. Papatriantafyllopoulou, T. C. Stamatatos, C. G. Efthymiou, L. Cunha-Silva, F. A. A. Paz, S. P. Perlepes and G. Christou, Inorg. Chem., 2010, 49, 9743; A. Escuer, G. Vlahopoulou, S. P. Perlepes and F. A. Mautner, Inorg. Chem., 2011, 50, 2468; C. Papatriantafyllopoulou, T. C. Stamatatos, W. Wernsdorfer, S. J. Teat, A. J. Tasiopoulos, A. Escuer and S. P. Perlepes, Inorg. Chem., 2010, 49, 10486; K. F. Konidaris, V. Bekiari, E. Katsoulakou, C. P. Raptopoulou, V. Psycharis, E. Manessi-Zoupa, G. E. Kostakis and S. P. Perlepes, Dalton Trans., 2012, 41, 3797; K. F. Konidaris, C. D. Polyzou, G. E. Kostakis, A. J. Tasiopoulos, O. Roubeau, S. J. Teat, E. Manessi-Zoupa, A. K. Powell and S. P. Perlepes, Dalton Trans., 2012, 41, 2862.

4 A. B. Canaj, L. E. Nodaraki, A. Philippidis, D. I. Tzimopoulos, E. Fotopoulou, M. Siczek, T. Lis and C. J. Milios, RSC Adv., 2013, 3, 13214.

5 B. D. Pearson, R. A. Mitsch and N. H. Cromwell, J. Org. Chem., 1962, 27, 1674.

6 G. M. Sheldrick, Acta Crystallogr., Sect. A: Found. Crystallogr., 2008, 64, 112.

7 R. H. Laye and E. J. L. McInnes, Eur. J. Inorg. Chem., 2004, 2811; J. Spandl, I. Brüdgam and H. Hartl, Angew. Chem., Int. Ed., 2001, 40, 4018.

8 X. M. Zhang, Y. Z. Zheng, C. R. Li, W. X. Zhang and X. M. Chen, Cryst. Growth Des., 2007, 7, 980; T. Nakamoto, M. Hanaya, M. Katada, K. Endo, S. Kitagawa and H. Sano, Inorg.Chem., 1997, 36, 4347.

9 A. W. Addison, T. N. Rao, J. Reedijk, J. van Rijn and G. C. Verschoor, Dalton Trans., 1984, 1349.

10 R. L. Carlin, Magnetochemistry, Springer-Verlag, Berlin, 1986; O. Kahn, Molecular Magnetism, Wiley-VCH, NewYork, 1993.

11 Representative references and refs therein: F. Klöwer, Y. Lan, J. Nehrkorn, O. Waldmann, C. E. Anson and A. K. Powell, Chem.-Eur. J., 2009, 15, 7413; E. C. Yang, D. N. Hendrickson, W. Wernsdorfer, M. Nakano, L. N. Zakharov, R. D. Sommer, A. L. Rheingold, M. Ledezma-Gairaud and G. Christou, J. Appl. Phys., 2002, 91, 7382; Y.-Z. Zhang, W. Wernsdorfer, F. Pan, Z.-M. Wang and S. Gao, Chem. Commun., 2006, 3302; O. Waldmann, M. Ruben, U. Ziener, P. Müller and J. M. Lehn, Inorg. Chem., 2006, 45, 6535; H. Andres, J. M. Clemente-Juan, M. Aebersold, J. M. Güdel, E. Coronado, H. Buettner, G. Kearly, J. Melero and R. Burriel, J. Am. Chem. Soc., 1999, 121, 10028; A. V. Palii, B. S. Tsukerblat, E. Coronado, J. M. Clement-Juan and J. J. Borras-Almenar, Inorg. Chem., 2003, 42, 2455; L. Banci, A. Bencini, C. Benelli, D. Gatteschi and C. Zanchini, Struct. Bonding, 1982, 52, 37; R. Boča, Struct. Bonding, 2006, 117, 1; M. MoraguesCanovás, C. E. Talbot-Eeckelaers, L. Catala, F. Lloret, W. Wernsdorfer, E. K. Brechin and T. Mallah, Inorg. Chem., 2006, 45, 7038; J. M. Clemente-Juan, E. Coronado, A. GaitaAriño, C. Giménez-Saiz, H.-U. Güdel, A. Sieber, R. Bircher and H. Mutua, Inorg. Chem., 2005, 44, 3389; J. M. Clemente-Juan, E. Coronado, A. Forment-Aliaga, J. R. Galan-Mascaros, C. Gimenez-Saiz and C. J. GomezGarcia, Inorg. Chem., 2004, 43, 2689.

12 L. Wang, Y. Li, Y. Peng, Z. Liang, J. Yu and R. Xu, Dalton Trans., 2012, 41, 6242; L. Lisnard, F. Tuna, A. Candini, M. Affronte, R. E. P. Winpenny and E. J. L. McInnes, Angew. Chem., Int. Ed., 2008, 47, 9695.

13 V. Tudor, G. Marin, F. Lloret, V. C. Kravtsov, Y. A. Simonov, M. Julve and M. Andruh, Inorg. Chim. Acta, 2008, 361, 3446. 14 V. Niel, V. A. Milway, L. N. Dawe, H. Grove, S. S. Tandon, T. S. M. Abedin, T. L. Kelly, E. C. Spencer, J. A. K. Howard, J. L. Collins, D. O. Miller and L. K. Thompson, Inorg. Chem., 2008, 47, 176.

15 R. Pattacini, P. Teo, J. Zhang, Y. Lan, A. K. Powell, J. Nehrkorn, O. Waldmann, T. S. A. Hor and P. Braunstein, Dalton Trans., 2011, 40, 10526.

16 T. K. Ronson, H. Nowell, A. Westcott and M. J. Hardie, Chem. Commun., 2011, 47, 176.

17 S. H. Zhang, L. F. Ma, H. H. Zou, Y. G. Wang, H. Liang and M. H. Zeng, Dalton Trans., 2011, 40, 11402.

18 A. Ferguson, A. Parkin, J. Sanchez-Benitez, K. Kamenev, W. Wernsdorfer and M. Murrie, Chem. Commun., 2007, 3473.

19 H. Ackermann, R. Leo, W. Massa and K. Dehnicke, Z. Anorg. Allg. Chem., 2000, 626, 608.

20 X. T. Wang, B. W. Wang, Z. M. Wang, W. Zhang and S. Gao, Inorg. Chim. Acta, 2008, 361, 3895.

21 A. A. Kitos, C. G. Efthymiou, C. Papatriantafyllopoulou, V. Nastopoulos, A. J. Tasiopoulos, M. J. Manos, W. Wernsdorfer, G. Christou and S. P. Perlepes, Polyhedron, 2011, 30, 2987.

22 Y. L. Zhou, M. H. Zeng, L. Q. Wei, B. W. Li and M. Kurmoo, Chem. Mater., 2010, 22, 4295.

23 A. A. Sidorov, M. E. Nikiforova, E. V. Pakhmutova, G. G. Aleksandrov, V. N. Ikorskii, V. M. Novotortsev, I. L. Eremenko and I. I. Moiseev, Izv. Akad. Nauk SSSR, Ser. Khim. (Russ.) (Russ. Chem. Bull.), 2006, 1851.

24 L. F. Chibotaru, L. Ungur, C. Aronica, H. Elmoll, G. Pilet and D. Luneau, J. Am. Chem. Soc., 2008, 130, 12445.

25 Q. Chen, M. H. Zeng, Y. L. Zhou, H. H. Zou and M. Kurmoo, Chem. Mater., 2010, 22, 2114.

26 L. Q. Wei, B. W. Li, S. Hua and M. H. Zeng, CrystEngComm, 2011, 13, 510. 
27 G. Aromi, A. S. Batsanov, P. Christian, M. Helliwell, A. Parkin, S. Parsons, A. A. Smith, G. A. Timco and R. E. P. Winpenny, Chem.-Eur. J., 2003, 9, 5142.

28 M. Moragues-Canovas, C. E. Talbot-Eeckelaers, L. Catala, F. Lloret, W. Wernsdorfer, E. K. Brechin and T. Mallah, Inorg. Chem., 2006, 45, 7038.

29 F. Cecconi, C. A. Ghilardi, S. Midollini and A. Orlandini, Inorg. Chim. Acta, 1991, 184, 141.

$30 \mathrm{~S}$. H. Zhang, Y. Song, H. Liang and M. H. Zeng, CrystEngComm, 2009, 11, 865.

31 Y. Z. Zhang, W. Wernsdorfer, F. Pan, Z. M. Wang and S. Gao, Chem. Commun., 2006, 3302.

32 S. T. Meally, C. McDonald, P. Kealy, S. M. Taylor, E. K. Brechin and L. F. Jones, Dalton Trans., 2012, 41, 5610.

33 G. Christou, K. S. Hagen and R. H. Holm, J. Am. Chem. Soc., 1982, 104, 1744.

34 H. Link and D. Fenske, Z. Anorg. Allg. Chem., 1999, 625, 1878. 35 G. Christou, K. S. Hagen, J. K. Bashkin and R. H. Holm, Inorg. Chem., 1985, 24, 1010.

36 D. Aguila, L. A. Barrios, O. Roubeau, S. J. Teat and G. Aromi, Chem. Commun., 2011, 47, 707.

37 X. N. Chen, W. Xue, J. B. Lin and X. M. Chen, Chem. Commun., 2010, 46, 246.

38 M. Hong, W. Su, R. Cao, F. Jiang, H. Liu and J. Lu, Inorg. Chim. Acta, 1998, 274, 229.

39 E. Fursova, O. Kuznetsova, V. Ovcharenko, G. Romanenko, V. Ikorskii, I. Eremenko and A. Sidorov, Polyhedron, 2007, 26, 2079.

40 N. Berg, S. M. Taylor, A. Prescimone, E. K. Brechin and L. F. Jones, CrystEngComm, 2012, 14, 2732.

41 D. B. Dell'Amico, C. Bradicich, F. Calderazzo, A. Guarini, L. Labella, F. Marchetti and A. Tomei, Inorg. Chem., 2002, 41, 2814.

42 J. K. Beattie, T. W. Hambley, J. A. Klepetko, A. F. Masters and P. Turner, Chem. Commun., 1998, 45.

43 J. K. Beattie, T. W. Hambley, J. A. Klepetko, A. F. Masters and P. Turner, Polyhedron, 1997, 16, 2109.

44 S. J. Langley, M. Helliwell, R. Sessoli, P. Rosa, W. Wernsdorfer and R. E. P. Winpenny, Chem. Commun., 2005, 5029.
45 M. Dinca, T. D. Harris, A. T. Iavarone and J. R. Long, J. Mol. Struct., 2008, 890, 139.

46 T. Shiga, T. Matsumoto, M. Noguchi, T. Onuki, N. Hoshino, G. N. Newton, M. Nakano and H. Oshio, Chem.-Asian J., 2009, 4, 1660.

47 C. Cadiou, R. A. Coxall, A. Graham, A. Harrison, M. Helliwell, S. Parsons and R. E. P. Winpenny, Chem. Commun., 2002, 1106.

48 Y. Bi, W. Liao, G. Xu, R. Deng, M. Wang, Z. Wu, S. Gao and H. Zhang, Inorg. Chem., 2010, 49, 7735.

49 S. Akine, W. Dong and T. Nabeshima, Inorg. Chem., 2006, 45, 4677.

50 R. W. Saalfrank, V. Seitz, F. W. Heinemann, C. Gobel and R. Herbst-Irmer, J. Chem. Soc., Dalton Trans., 2001, 599.

51 A. A. Sidorov, I. G. Fomina, M. O. Ponina, G. G. Aleksandrov, S. E. Nefedov, I. L. Eremenko and I. I. Moiseev, Izv. Akad. Nauk SSSR, Ser. Khim. (Russ.) (Russ. Chem. Bull.), 2000, 960.

52 A. A. Sidorov, I. G. Fomina, S. S. Talismanov, G. G. Aleksandrov, V. M. Novotortsev, S. E. Nefedov and I. L. Eremenko, Koord. Khim. (Russ.) (Coord. Chem.), 2001, 27, 584.

53 C. Cadiou, M. Helliwell and R. E. P. Winpenny, C. R. Chim., 2003, 6, 241.

54 C. Benelli, A. J. Blake, E. K. Brechin, S. J. Coles, A. Graham, S. G. Harris, S. Meier, A. Parkin, S. Parsons, A. M. Seddon and R. E. P. Winpenny, Chem.-Eur. J., 2000, 6, 883.

55 E. Fursova, O. Kuznetsova, V. Ovcharenko, G. Romanenko, V. Ikorskii, I. Eremenko and A. Sidorov, Polyhedron, 2007, 26, 2079.

56 A. Graham, S. Meier, S. Parsons and R. E. P. Winpenny, Chem. Commun., 2000, 811.

57 S. Langley, M. Heliwell, R. Sessoli, S. J. Teat and R. E. P. Winpenny, Inorg. Chem., 2008, 47, 497.

58 H. N. Miras, I. Chakraborty and R. G. Raptis, Chem. Commun., 2010, 46, 2569.

59 S. K. Langley, M. Helliwell, S. J. Teat and R. E. P. Winpenny, Dalton Trans., 2012, 41, 12807. 